\title{
Comprehensive Wealth of Immigrants and Natives
}

\author{
David Love and Lucie Schmidt
}




\title{
Comprehensive Wealth of Immigrants and Natives
}

\author{
David Love \\ Williams College
}

Lucie Schmidt

Williams College

September 2015

\author{
Michigan Retirement Research Center \\ University of Michigan \\ P.O. Box 1248 \\ Ann Arbor, MI 48104 \\ www.mrrc.isr.umich.edu \\ (734) 615-0422
}

\section{Acknowledgements}

The research reported herein was performed pursuant to a grant from the U.S. Social Security Administration (SSA) funded as part of the Retirement Research Consortium through the University of Michigan Retirement Research Center (5 RRC08098401-07). The opinions and conclusions expressed are solely those of the author(s) and do not represent the opinions or policy of SSA or any agency of the Federal Government. Neither the United States Government or any agency thereof, or any of their employees, makes any warranty, express or implied, or assumes any legal liability or responsibility for the accuracy, completeness, or usefulness of the contents of this report. Reference herein to any specific commercial product, process or service by trade name, trademark, manufacturer, or otherwise does not necessarily constitute or imply endorsement, recommendation or favoring by the United States Government or any agency thereof.

\section{Regents of the University of Michigan}

Michael J. Behm, Grand Blanc; Mark J. Bernstein, Ann Arbor; Laurence B. Deitch, Bloomfield Hills; Shauna Ryder Diggs, Grosse Pointe; Denise Ilitch, Bingham Farms; Andrea Fischer Newman, Ann Arbor; Andrew C. Richner, Grosse Pointe Park; Katherine E. White, Ann Arbor; Mark S. Schlissel, ex officio 


\title{
Comprehensive Wealth of Immigrants and Natives
}

\begin{abstract}
The 1965 Immigration and Nationality Act had a profound impact on the demographic and skill composition of immigrants arriving in the United States. A large literature has investigated the relative earnings of immigrants and natives, but much less is known about relative wealth accumulation and the preparation of immigrants for retirement. This paper compares the retirement preparation of older immigrants to that of native-born households using an annualized comprehensive measure of available resources. We find that immigrants have less wealth overall, but that they appear to be drawing down resources at a slower rate. We attempt to make sense of the trends in annualized wealth with the help of a life-cycle framework that incorporates uncertain longevity, bequests, risk in retirement resources, as well as endogenous housing wealth. Simulations from the model indicate that it is difficult to match the observed patterns in annualized wealth without the combination of both an explicit bequest motive and an explicit treatment of housing choice. These patterns mask a good deal of heterogeneity, however, in terms of socioeconomic and demographic characteristics. Some of the largest differences within immigrants occur along the margins of race and ethnicity, as well as the number of years since arrival. The evidence suggests that the typical immigrant is relatively well situated in retirement, but that more recent immigrants have low levels of total resources and are likely to have difficulty maintaining adequate levels of spending in retirement.
\end{abstract}

\section{Citation}

Love, David, and Lucie Schmidt. 2015. “Comprehensive Wealth of Immigrants and Natives.” Ann Arbor, MI. University of Michigan Retirement Research Center (MRRC) Working Paper, WP 2015-328. http://www.mrrc.isr.umich.edu/publications/papers/pdf/wp328.pdf

\section{Authors' acknowledgements}

We are grateful for funding from the Michigan Retirement Research Center, and for the excellent research assistance of Jesse Freeman and Rebecca Lewis. We also benefited from the helpful feedback from seminar participants at the 2014 MRRC Workshop, the 17th Annual RRC Conference (with special thanks to our discussant, Maria Enchautegui), Williams College, and Goethe University. The research reported herein was performed pursuant to a grant from the U.S. Social Security Administration (SSA) funded as part of the Retirement Research Consortium. The opinions and conclusions expressed are solely those of the author(s) and do not represent the opinions or policy of SSA or any agency of the Federal Government. 


\section{Introduction}

The 1965 Immigration and Nationality Act, which replaced a national-origins quota system with one based on family ties and skilled labor demand, had a profound impact on the demographic and skill composition of immigrants arriving in the U.S ${ }^{1}$ While a large literature has investigated the effects of this changing composition and other labor market trends on the relative earnings of immigrants and natives: $\sqrt[2]{ }$ much less is known about relative wealth accumulation and the preparation of immigrants for retirement. One motivation for learning more about immigrant wealth is that the earliest waves of the post-1965 immigrants are just reaching retirement age, and their experiences may serve as a bellwether for the retirement savings behavior of future immigrants. In addition, the retirement resources of immigrants could have important implications for immigration policy. Some researchers have argued that more expansive immigration policy would help relieve the pressure on Social Security and Medicare (e.g., Lee and Miller, 2000; Storesletten, 2000; SSA, 2010). Others argue for more restrictive immigration policy due to worries that immigrants might be a net burden on transfer programs $\mathrm{H}^{3}$ Understanding more about immigrant wealth is therefore important from the perspectives of both welfare economics and public policy.

Existing evidence suggests some notable differences in retirement resources between immigrants and the native-born. First, immigrants have significantly lower Social Security benefits, even after controlling for a wide array of socioeconomic and demographic characteristics, largely due to the fact that they have fewer quarters of Social Security covered earnings (Cohen and Iams, 2007\% Favreault and Nichols, 2011; Sevak and Schmidt, 2014). In addition, immigrants also have lower rates of private pension coverage, largely as a result of employment patterns (Heim et al., 2012). The combination of low future Social Security benefits and reduced pension coverage means that immigrants have less wealth in the form of annuities and are therefore more exposed to the risk of outliving their assets. According to a standard lifecycle model, they should be compensating for this in one of two ways-either by saving relatively more private wealth, or by spending down their private wealth more slowly. In addition, previous literature suggests that both years in the U.S. and country of origin matter significantly in

\footnotetext{
${ }^{1}$ Previous policy prioritized Western European immigrants and largely excluded immigrants from Asia, Africa, and Latin America.

${ }^{2}$ See Borjas (1999), Blau et al. (2003), and Duleep and Dowhan (2008) for reviews of this literature.

${ }^{3}$ See Kerr and Kerr (2013) for a recent review of the literature on the economic impact of immigration on social benefits.
} 
explaining immigrant-native differentials in retirement resources.

In this paper, we build on the previous literature in several important ways. First, we calculate measures of comprehensive wealth for immigrants and natives using data from the 1998-2012 waves of the Health and Retirement Study (HRS). Comprehensive wealth is a measure of household resources that includes total financial and non-financial assets, plus annuitized assets such as Social Security and defined-benefit (DB) pensions (Love et al., 2008, 2009). The comprehensive balance sheet provides insights into immigrant-native differences in retirement preparation that are not available through standard measures of net worth alone $4^{4}$ We then examine median profiles of an annualized equivalent of comprehensive wealth over the retirement period. For a household of a given age, the annualized measure is equivalent to the income derived from a real, joint-life annuity purchased with the full value of comprehensive wealth. In contrast to the levels of comprehensive wealth, trajectories of annualized wealth indicate whether households are drawing down resources faster or more slowly than a simple life cycle model would predict. We attempt to make sense of the patterns of annualized wealth with the help of a lifecycle framework that incorporates some likely suspects for explaining the observed trajectories: uncertain longevity, an explicit bequest motive, precautionary saving in retirement, and housing. Finally, we estimate descriptive median regressions of annualized wealth to see whether immigrantnative gaps can be explained by observable characteristics, and to examine the extent of convergence in annualized resources across different cohorts of immigrants in the U.S.

We find that immigrants have significantly lower levels of comprehensive wealth, but that there is a great deal of heterogeneity within the immigrant population, particularly along the dimension of years of arrival in the U.S. More recent waves of immigrants have substantially less wealth in all forms (financial, non-financial, and annuitized) compared to earlier waves of immigrants and natives. Race and ethnicity appear equally important for understanding wealth differences. White and nonwhite/nonHispanic immigrant households actually appear better prepared for retirement than comparable natives, suggesting the much of the overall gap in resources can be accounted for by the lower wealth holdings of Hispanics. Annualized comprehensive wealth for both immigrants and natives rises with age. However, it is rising even faster for immigrants, which implies that immigrants are spending down retire-

\footnotetext{
${ }^{4}$ For example, the present value measures of future pensions and Social Security are likely to differ substantially between recently arrived immigrants and natives since pension formulas depend on years of service, and Social Security benefits are a function of covered earnings.
} 
ment resources less quickly. Non-financial wealth (including housing) appears to play a particularly important role for immigrants, in that they have both a higher share of this form of wealth and different patterns of non-financial wealth than natives.

The annualized wealth profiles of immigrants and natives are consistent with the predictions of a lifecycle model that allows for uncertain longevity, retirement income risk, explicit bequest motives, and housing. In particular, we find that a combination of housing and a bequest motive provides the key to understanding the rising annualized wealth patterns in the data. Across a wide number of specifications, the only way that we can consistently produce upward sloping annualized wealth profiles is by allowing for differences in home ownership and bequest motives. Home ownership patterns appear to play a fundamental role in understanding not just overall rates of dissaving in retirement, but also, potentially, the slower drawdown rates of (the relatively housing rich) immigrant population.

Finally, median regressions of the levels of annualized wealth help us investigate a more nuanced set of factors that could be driving the annualized wealth patterns of immigrants and natives, especially with regards to the importance of immigrant cohort effects. Working through regression specifications that include controls for demographic information, life-cycle factors, and immigrant origins, we find that more recent immigrant cohorts continue to show lower levels of annualized wealth, even after controlling for a wide set of observables. These results suggest that more recent waves of immigrants may be particularly vulnerable, arriving in retirement with substantially lower resources than those of immigrants who arrived before the 1965 Immigration Act.

\section{Background}

\subsection{Immigrants and Social Security}

Current Social Security rules imply that immigrants are likely to receive lower benefits than the nativeborn. Eligibility for Social Security benefits requires that one has worked for 40 covered quarters, leaving many immigrants with insufficient quarters of covered earnings (or reported earnings) to qualify. Empirical evidence largely confirms this - immigrants have lower actual and projected Social Security benefits, even after extensive controls for health and socioeconomic characteristics. Cohen and Iams (2007) use a microsimulation model to predict Social Security and other retirement resources, 
and project that the foreign-born will be significantly less likely to receive Social Security benefits. Favreault and Nichols (2011) link the Survey of Income and Program Participation to administrative Social Security records and find that immigrants have lower Social Security benefits than natives, but that this is primarily driven by immigrants from less developed countries. They also find that immigrants are much more likely to have made contributions but not be eligible for benefits. Sevak and Schmidt (2014) use the Health and Retirement Study linked to Social Security earnings histories and show that immigrants have significantly lower predicted Social Security benefits, but that this gap is strongly related to years in the United States, and is entirely explained by differences in covered quarters of earnings.

However, this disadvantage is mitigated in two important ways. First, since the Social Security benefit formula is progressive, immigrants may experience a higher replacement rate than natives (Gustman and Steinmeier, 2000b). Second, work by Borjas (2010) shows that older immigrants may have higher employment rates than comparable natives, in part to accumulate the necessary work credits for Social Security.

\subsection{Immigrants and Private Wealth}

Despite the lower Social Security benefits found in much of the previous literature, immigrants may be adequately prepared for retirement if they have amassed sufficient private wealth to compensate for their lower Social Security benefits. However, this does not appear to be the case. Although there is great heterogeneity within the immigrant population, immigrants have relatively lower savings rates (Carroll et al., 1994, 1999); exhibit significantly different patterns of portfolio allocation (CobbClark and Hildebrand, 2006; Osili and Paulson, 2009); and have relatively lower levels of net worth and projected retirement well-being (Cobb-Clark and Hildebrand, 2006; Favreault and Nichols, 2011). Sevak and Schmidt (2014) also find that average private net worth is significantly lower for immigrants. However, after controlling for differences in education, race, and ethnicity, immigrant households have significantly higher net worth than similarly situated native-born households. In addition, immigrants have lower levels of private pension coverage than natives (Osili and Paulson, 2009, Heim et al., 2012, Sevak and Schmidt, 2014). Heim et al. (2012) finds that this participation gap is primarily due to immigrants being less likely to work for firms that offer pension plans, rather than differential take-up 
rates.

One particularly interesting component of private wealth when considering immigrant/native differentials is housing. Non-economists have written on the significance of homeownership to immigrants as a symbol of assimilation (Anacker, 2013). Previous research shows that immigrants are significantly less likely to own homes than natives (Borjas, 2002; Cobb-Clark and Hildebrand, 2006; Sevak and Schmidt, 2014). However, conditional on home ownership, immigrants have higher levels of home equity, even before controlling for observable characteristics (Chatterjee and Zahirovic-Herbert, 2011; Sevak and Schmidt, 2014). Drew (2002) finds that the median value of first-time home purchases among the foreign-born was $50 \%$ higher than that of the native-born, and that as a result immigrants were making larger down payments and acquiring larger levels of home equity. This is in part due to the concentration of immigrants in areas with high housing costs like California and New York. Similarly, Borjas (2002) finds that observable demographic characteristics do not explain much of the homeownership gap between immigrants and natives, but that residential location choices are important.

\subsection{Comprehensive and Annualized Wealth}

Narrower definitions of net worth that ignore public and private pension benefits tend to overstate the extent of under-saving. Gustman and Steinmeier, for example, have shown in a series of fundamental papers that properly accounting for pension and Social Security benefits changes the picture of wealth accumulation in retirement (Gustman and Steinmeier, 1999, Gustman et al., 2010). They find that a substantial portion of the income distribution appears relatively well prepared for retirement and that some of this reflects the increasing generosity of pension coverage and provisions between 1969 and 1992 (Gustman and Steinmeier, 2000a). These results are consistent with the evidence in other studies examining comprehensive measures of wealth (Haveman et al., 2006; Love et al., 2008), though it is worth keeping in mind that there is considerable heterogeneity in the composition and drawdown of resources in retirement (Poterba et al., 2011). Poterba et al. (2012), for example, examine ex-post income and wealth outcomes at the point of death and find that while resources are substantial at the median, a large number of households die with low income and low financial and housing wealth.

It is also the case that the notion of "adequate" retirement resources depends crucially on the assumptions used to model wealth targets (Poterba, 2015). Studies that define households as "at risk" if 
they cannot maintain current levels of consumption in retirement tend to find higher fractions of households with low savings (Munnell et al., 2006; VanDerhei and Copeland, 2010; Munnell et al., 2012). In constrast, studies comparing household wealth accumulation to the predictions of a life cycle model find that a large majority of households are actually saving more than their optimal life-cycle targets (Engen et al., 1999, 2005; Scholz et al., 2006).

Perhaps the most striking finding in the comprehensive wealth literature is that households tend to draw down retirement assets much more slowly than a standard lifecycle model would predict. Households appear to be cautious in drawing down wealth at the top quintiles of the distribution (Smith et al., 2009), and annualized wealth trajectories rise markedly for the median household (Love et al., 2009). De Nardi et al. (2015) document similar decumulation patterns and suggest that a combination differential survival rates, out-of-pocket medical expenses, bequest motives, and housing may help reconcile the data with predictions from the model.

\section{Retirement Resources of Immigrants and Natives}

\subsection{Data}

We examine immigrant and native retirement resources for households with respondents aged 51 years or older using 8 waves of data from the HRS spanning 1998-2012 5 The HRS has a number of advantages for studies of comprehensive wealth relative to other national surveys. As described in detail in Smith (1995), the HRS questionnaire was specifically designed to minimize issues of bias in measures of wealth by including the use of unfolding brackets. Consequently, HRS provides a more complete picture of private wealth than most other data sets. The HRS closely matches the wealth distribution from the cross-sectional Survey of Consumer Finances (SCF) for all but the top 1\%, in which the HRS underreports wealth relative to the SCF (Sierminska et al., 2008). We focus on the behavior of the median household, however, so the discrepancy at the top percent of the wealth distribution should not have an important impact on our analysis.

\footnotetext{
${ }^{5}$ The HRS is sponsored by the National Institute on Aging (grant number NIA U01AG009740) and is conducted by the University of Michigan. We use the RAND HRS Data File, version N, as well as the wave-specific RAND fat files. The RAND version of the HRS consists of an easy-to-use longitudinal file (the main file) and wave-specific enhanced "fat files" that can be merged at the respondent level. The RAND HRS was developed with the help of funding from the National Institute on Aging and the Social Security Administration.
} 
In addition to the publicly available HRS data, we also use restricted data on geography (CrossWave Geographic Information (Detail) [1992-2012]) and Social Security earnings records (Respondent Cross-Year Summary Earnings from the SSA). The restricted data on geography contain information on country of origin, as well as state of current residence. The SSA restricted earnings data include information on Social Security covered earnings from 1951 to 2013, as well as on the pattern and duration of earnings.

This HRS panel includes six entry cohorts of respondents-the original HRS cohort introduced in 1992 (born 1931-1941), an older cohort from the 1993 AHEAD survey (born 1923 or earlier), the "Children of Depression" cohort (born 1924-1930), the "War Babies" (born 1941-1947), the "Early Boomers" (born 1948-1953), and the "Mid Boomers" (born 1954-1959), who entered the survey in 2012. Approximately $11 \%$ of HRS respondents are foreign-born, though the rate varies by birth cohort (10\% of those born 1931-1941, 8\% of those born 1942-1947 and 14\% of those born 1948-1953). The availability of longitudinal data on multiple birth cohorts allows us to simultaneously examine wealth trajectories by age and by birth cohort.

\subsection{Comprehensive and Annualized Wealth}

\subsubsection{Comprehensive wealth}

We follow Gustman and Steinmeier (1999), Wolff (2007), Gustman et al. (2009), and Love et al. (2009) in constructing a comprehensive measure of the household balance sheet that includes both conventional sources of net worth, as well as the actuarial present value of expected future streams of income derived from pensions, Social Security, annuities, future earnings up to age 65, and other social insurance programs. Apart from the usual concerns about measurement error in survey wealth data (see Gustman et al., 1997), the calculation of the financial and non-financial components of comprehensive wealth is straightforward. The financial component includes stocks, bonds, checking accounts, CDs, Treasuries, defined contribution (DC) pensions, individual retirement accounts (IRAs) and Keoghs, and other savings, less non-vehicle and non-housing debt. Non-financial comprehensive wealth includes the net value of primary and secondary housing, the net value of vehicles, and any investment and business real estate less associated debt. 
Measuring the contribution of annualized sources to comprehensive wealth is more challenging. We calculate the present value of expected future annualized streams of payments by making a set of assumptions about discount rates, survival probabilities, marital transitions, and, implicitly, about the intertemporal fungibility of future sources of income. By far the most important source of future income for most U.S. households (and most HRS households) is Social Security. The HRS asks respondents about both current and expected future Social Security benefits for themselves and for their spouses, if married. These are self-reported values, and the reported levels of current Social Security benefits tend, not surprisingly, to be more accurate than those of expected future benefits. Our measure of the present value of Social Security discounts future benefits by the relevant survival probabilities obtained from the 2010 Social Security Administration Life Tables and adjusts for widow's benefits. Our measure does not, however, account for the possibility that married couples might divorce during the retirement period, and it does not allow for differential mortality on dimensions other than gender 6 While we have experimented with various interest rates for discounting the stream of benefits (including using the full yield curve on Treasury debt), we assume a $2.5 \%$ real rate of return for the results presented in the main tables.

The present value calculation for defined-benefit (DB) pensions, veteran's benefits, earnings up to age 65, annuities, and other sources of future non-labor income follows a similar procedure, except that we discount using a nominal rate of return with a $2 \%$ expected inflation rate, and we only include a cost-of-living adjustment and spousal benefits if respondents report these in the survey[7] To the extent that reporting errors and overall levels of plan information vary randomly across respondents, the self-reported measures primarily increase the noisiness of our comprehensive wealth estimates. If, however, information about plan type and plan characteristics depends systematically on demographics, resources, or (most importantly) immigration status, our measure may introduce an important additional source of bias into our measure of total household resources.

Table 1 reports weighted means and medians of comprehensive wealth categories by age and marital status. Immigrants generally have significantly lower levels of comprehensive wealth at the mean,

\footnotetext{
6 Sevak and Schmidt (2008) find that immigrants experience lower age-specific mortality rates.

7 As Gustman et al. (2010) discuss in their book on pensions in the HRS, the self-reported pension measures in the HRS show substantial amounts of reporting error and confusion on the part of some respondents about pension plan type, despite the fact that the HRS asks detailed follow-up questions of respondents with inconsistent answers about plan type and features.
} 
with the exception of single females. At the median, however, the comprehensive wealth differences between immigrants and natives are statistically and economically significant for all subgroups. Married immigrants, for example, hold between 59\% and 69\% as much wealth at the median as their native counterparts, depending on the age bracket.

\subsubsection{Annualized wealth}

One of the challenges in interpreting comprehensive wealth (or any measure of total household resources) is that it is difficult to say exactly how much wealth households need in order to finance an adequate retirement given differences in age and marital status. In order to understand the implications of different levels and trajectories of comprehensive wealth, we now turn to a measure of annualized household resources that adjusts for longevity and household composition over the retirement horizon (Love et al., 2009). The basic idea is to imagine that a household uses its entire comprehensive wealth to purchase an actuarially fair, real, joint-life annuity, whose price is computed using the genderspecific survival probabilities from the 2010 Social Security Administration Life Tables. The income level delivered by that annuity is our measure of "annualized wealth."

The motivation for annualizing wealth comes from the standard lifecycle model in which households consume their permanent income, as well as the literature on annuity markets (see, e.g., Brown and Poterba 2000). Since we observe relatively low demand for annuities, a joint-life annuity purchased with the full value of comprehensive wealth delivers an income flow that should generate at least as high a level of welfare as could be obtained with an optimal strategy of wealth decumulation and annuitization 8

\subsection{Wealth Profiles}

In order to provide a broad look at the evolution of retirement wealth for immigrants and natives, we begin by examining regression-based age profiles of comprehensive wealth using a technique developed in Love et al. (2009) 9 Figure 1 displays the age trajectories of median comprehensive wealth for

\footnotetext{
${ }^{8}$ This is true, at least, if we abstract somewhat from imperfect asset substitution (e.g., we are assuming that individuals can liquidate housing wealth with no transactions costs) and annuity market imperfections that lead to high loads and a limited market for inflation-adjusted annuities.

${ }^{9}$ The procedure involves four steps: (1) compute the two-year growth rate in wealth in the pooled HRS sample; (2) estimate a median regression of growth rates on five-year age dummies, household characteristics, and a set of survey year
} 
married immigrants and natives aged 60 to 90, where the ages are taken to be the median age within each of the 5-year age brackets ${ }^{10}$ Two striking features are worth noting. The first is the substantial gap in comprehensive wealth at all ages between immigrants and natives. Natives begin retirement with over $\$ 1$ million in comprehensive wealth, which falls to less than half that amount at age 90 . Immigrants, in contrast, start off with only about $\$ 600,000$ in resources and hold less wealth at all ages compared to natives. Despite the initial differences in levels, however, the wealth gap between the two groups converges markedly over retirement. While natives hold about twice as much comprehensive wealth at the onset of retirement, they have only $40 \%$ more in ages $85-90$. At the median, immigrants appear to be drawing down retirement resources at a slower rate than natives.

While comprehensive wealth declines with age for both natives and immigrants, it is unclear whether this means that resources are rising or falling in annual terms. Figure 2 displays trajectories of annualized wealth for both immigrant and native married couples using the same median-regressionbased technique. The annualized profiles for both groups slope upwards (though only slightly in the case of natives), which is consistent with the findings in Love et al. (2009). In addition, the profiles for immigrants and natives tend to converge with age. Immigrants start off retirement with annualized wealth about $\$ 15,000$ lower than that held by natives, but the difference narrows by a third by age 80 and then levels off at ages 85-90. Thus, while both married natives and immigrants appear to be drawing down resources at a rate slower than a simple life-cycle framework would predict, there is some evidence that immigrants are especially slow in spending down retirement wealth 11

dummies; (3) construct predicted growth rates for each age dummy; and (4) cumulate the predicted growth rates and "anchor" the profiles using the age-70 levels of median wealth. The advantage of the technique is that it helps mitigate survivorship bias and cohort effects that may induce differences in the observed levels of wealth for different ages at a given point in time. In particular, by using the growth rates of median wealth from one wave to the next, we eliminate the possibility of non-random attrition since the growth rates are necessarily calculated for survivors. Further, since the growth rates of wealth tend to differ much less than the levels for survivors versus non-survivors (see Love et al. 2009), the regression-based approach further reduces the second source of bias as well.

${ }^{10}$ Households are considered married if they report being married in the first wave they are observed in our sample. The sample therefore includes some individuals who were married in earlier waves but later transitioned into divorce or widowhood. In the figures, we define a married immigrant household as one in which both the respondent and the spouse are born outside the U.S. This gives us the largest measured immigrant-wealth gaps, since couples with one immigrant and one native tend to have higher levels of wealth than couples with two immigrants. We consider a more flexible definition of married immigrant households in the regression analysis below.

${ }^{11}$ As with the comprehensive wealth profiles, the slope of the profiles may reflect other factors as well, such as capital gains in housing and financial assets that disproportionately benefited older households or cohort effects. Given the sharp differences in wealth holdings between recent and earlier immigrants, it is indeed likely that cohort differences may be driving some of the upward slope in annualized wealth. Note, however, that the cohort story has to involve differences in the growth rate of wealth and not just levels, given that the profiles are based on predicted median growth rates of annualized wealth. 
One drawback to our growth-based method of tracing median annualized wealth is that median growth rates need not correspond to the median levels of annualized growth, which are used to anchor the trajectories in Figure 2. Suppose, for example, that our sample consisted of only three households: A, B, and C. Household A has an annual wealth level of $\$ 20,000$ and a growth rate of 5\%. Household $\mathrm{B}$ has an annual wealth level of $\$ 50,000$ and a growth rate of $2 \%$. And household $\mathrm{C}$ has an annual wealth level of $\$ 70,000$ and a growth rate of $7 \%$. In this case, household B has the median level of annual wealth $(\$ 50,000)$, while household $A$ has the median growth rate of wealth $(5 \%)$. The median wealth trajectories in this case would reflect wealth information from two distinct households, showing a growth rate of $5 \%$, but a level of $\$ 50,000$. Ideally, we would like to estimate growth-based profiles for households within a neighborhood of the median annualized wealth for each age bracket, but we do not have enough observations to accurately estimate growth rates for the age cells used to construct Figure 2. We can, however, line up the median growth rates and levels if we are willing to consider much wider age brackets.

Table 2 reports the levels and percent annual growth rates of annualized wealth and its main components for married households with annualized wealth plus or minus $25 \%$ of the median annualized wealth level for each age and immigration status group. In terms of levels, we see the importance of non-financial wealth for immigrants. Despite having substantially lower median annualized wealth levels than natives, immigrants have similar levels of annual housing wealth in the first retirement period (ages 65-74) and markedly more in the second retirement period (ages 75-85). This difference is also reflected in the shares of non-financial wealth (not shown in the table), with immigrants aged 75-85 holding about 10 percentage points more of their portfolios in the form of non-financial wealth.

The estimated median leves and growth rates suggest that the immigrant households near the median of annualized wealth experience faster growth in annualized nonfinancial wealth compared to natives. The growth rate differences persist across all of the age groups, and they rise substantially in the oldest group. Most of the differential growth in non-financial annualized wealth appears to be due to housing. For example, while natives ages 75-85 saw an annual increase in annual housing wealth of about $6.2 \%$ over the sample period, immigrants in the same age bracket experienced an increase over twice as large. 


\section{Annualized Wealth in the Life-Cycle Model}

The results in Table 2 also highlight an important aspect of the annualized wealth trajectories. Because financial wealth is so small for households near the median annualized wealth level, and because annuitized wealth (mostly in the form of pensions and Social Security) remains, by its nature, roughly constant in annual terms, the lion's share of the increase in annualized wealth over the retirement period for both natives and immigrants must come from non-financial wealth in the form of housing. This, however, does not provide an explanation for why non-financial wealth declines at a slower pace than financial and annuitized wealth. Before turning to a regression analysis of the covariates of annualized wealth, it is therefore helpful to see what a life-cycle model would predict for annualized wealth trajectories.

The phenomena we are trying to understand are the upward trajectory of annualized wealth in retirement and the potential role of housing in explaining differences beween the immigrant and native profiles. Previous work shows that a lifecycle model with uncertain longevity, medical expense risk, and an explicit bequest motive can match the rising median profiles of annualized wealth in the HRS for at least part of the retirement period (Love et al. 2009). The limitation of this framework, however, is that it does not provide a role for housing in explaining differences in wealth trajectories. As we will see, a combination of housing (with transactions costs) and a bequest motive can generate annualized wealth profiles of the kinds seen in Figure $2^{12}$

The model we consider extends the standard buffer-stock life-cycle model (see, e.g., Carroll 1997) by introducing roles for three key features that might help explain upward annualized wealth trajectories: uncertainty in retirement resources, an active bequest motive, and housing with transactions costs. The appendix provides a detailed description of the model and the solution technique. The basic setup, however, is straightforward. Individuals in the model can own or rent housing. Homeowners can borrow up to $80 \%$ of the value of the house, and there are transactions costs on buying or selling housing equal to $6 \%$ of the house value. Individuals enter each period knowing their non-housing net worth,

\footnotetext{
${ }^{12}$ While this is the first paper to our knowledge to investigate annualized wealth using a model of endogenous housing investment, we are not the first to introduce housing into the life-cycle framework. A partial list of important recent studies includes Gervais (2002), Cocco (2005), Yao and Zhang (2005), Li and Yao (2007), Campbell and Cocco (2007), Chen (2010), Iacoviello and Pavan (2012), and Díaz and Luengo-Prado (2010). Our setup is probably closest to Nakajima and Telyukova (2011), who estimate a structural model of housing in retirement to explain the dissaving behavior of homeowners and renters.
} 
house value, and current income net of medical costs. Households then choose how much to consume, whether to rent or own next period, and the house value next period. During the working years, earnings shocks lead to movements in both transitory and permanent income, while in retirement income net of medical costs changes only due to volatility in (persistent) out-of-pocket medical expenses.

\subsection{Simulated Annualized Wealth Profiles}

The four panels of Figure 4 show how these three key features (retirement risk, bequests, and housing) affect the annualized wealth profiles for high school graduates (the profiles for college graduates look qualitatively similar). Each panel displays profiles of annualized wealth for models with and without the possibility of home ownership. The models without housing are solved using the same parameters as the models with housing, except that households are only allowed to obtain housing services through the rental market. The top left panel of the figure corresponds to a baseline specification in which there is no income risk in retirement and no explicit bequest motive. The bottom left panel introduces retirement income risk. The top right panel adds bequests but no retirement risk. And the bottom right panel corresponds to both retirement income risk and a bequest motive.

The baseline specification of the figure indicates that a model without retirement risk or a bequest motive is unlikely to explain the upward sloping trajectories of annualized wealth. In the baseline specification without housing, annualized profiles turn sharply down in retirement, reflecting households' increasing rates of survival discounting. But even in the specification with housing, annualized wealth declines toward the end of retirement as households divest their stock of housing wealth to finance consumption during the tail end of life. Moreover, this is even true despite the fact that households in the model can extract - through reverse mortgages, presumably $-80 \%$ of the value of the house. Retirement risk alone is not enough to overcome survival discounting in retirement, even though it leads to higher levels of annualized wealth throughout retirement 13 The upper right panel of the figure indicates that bequests alone do not lead to an upward slope in annualized wealth, but that the combination of bequests and housing induces a pattern similar to that in the HRS data. Since housing and financial wealth are perfect substitutes for bequests, households have an incentive to maintain the same level of

\footnotetext{
${ }^{13}$ Retirement risk in the model does not change with age, however. It could be the case that rising uncertainty about medical expenses, for example, would be enough to offset the effects of survival discounting.
} 
housing through retirement in order to economize on housing costs and avoid paying the transactions costs associated with a house sale. The result is that the value of housing stays relatively flat even at advanced ages, which is enough to support a rising trajectory of annualized resources throughout the end of life 14

The interaction of housing and bequests plays a crucial role in explaining the trajectories of annualized wealth. Across a wide range of simulations, the only way that we can generate upward sloping annualized wealth paths was through combining an explicit bequest motive with the possibility of housing. Risk alone causes annualized wealth to rise at the onset of retirement, but the reduced probability of survival eventually outweighs the precautionary saving motive, and the profiles inevitably come back down. Likewise, bequests alone can generate a level increase in annualized wealth (with a sharp upward slope in the last couple of years as households approach the maximum age), but the declining survival probabilities still lead to a negative slope for the latter part of the retirement period. Regardless of the exact specification of the model, the basic mechanism of bequests supporting higher levels of housing in retirement is likely to hold.

Returning to the differential profiles of immigrants and natives shown in Figure 2 , these simulations point to a possible explanation for both the shared pattern of rising profiles, as well as the fact that immigrants tend to build up annualized resources at a faster rate. Conditional on homeownership, immigrants tend to hold substantially more wealth in the form of housing.

The simulated life-cycle profiles are helpful for identifying some of the key features that might explain the shape of the annualized wealth trajectories observed in the data. We are also interested, however, in understanding how annualized wealth depends on factors that pertain particularly to immigrants, including country of origin, immigration cohort, race, and ethnicity. Because it is not obvious how these factors can be incorporated in a life-cycle framework, the next section turns to a richer regression analysis of the covariates of annualized wealth for immigrants and natives.

\footnotetext{
${ }^{14}$ The rapid build up of annualized wealth in the last couple of years before the maximum possible age of 100 occurs because the model artificially truncates the possibility of living beyond age 100 and therefore artificially curtails the horizon in the joint-life annuity calculation, reducing the annuity price and increasing the amount of annual income corresponding to a given amount of total wealth.
} 


\section{Empirical Analysis of Native and Immigrant Wealth}

\subsection{Annualized wealth and demographics}

Table 3 reports weighted mean and median levels of annualized wealth by age (65-74 and 75-85), education, race and ethnicity, and immigration cohort (pre-1955, 1955-1964, 1965-1974, 1975-1984, and 1985+) for households married in the first wave they appear in the survey. We restrict the sample to households with an oldest member aged 51 or more. For both age groups, immigrants have lower median annualized wealth than their native counterparts at all education levels. The breakdown by race and ethnicity, however, suggests that white immigrants fare substantially better than white natives, particularly in the second half of retirement. Nonwhites have less annualized wealth overall, but the median annualized wealth of nonwhite immigrants is generally higher than that of nonwhite natives. This is consistent with work by Sevak and Schmidt(2014), which finds higher levels of total net worth for immigrants after controlling for demographic characteristics including race and ethnicity. However, this pattern does not hold for Hispanics, with native Hispanics holding almost twice as much annualized wealth than Hispanic immigrants at both the median and the mean.

One possible explanation could be that the wealth differences among Hispanics may be connected to the differences in wealth across arrival cohorts of immigrants. The table indicates that there are striking differences in annualized wealth by year of arrival in the U.S. The earliest group of immigrants (corresponding loosely to those arriving before the 1965 Act) has several times the mean annualized wealth as recent immigrants (arriving after 1985), and the differences at the median are almost as large. Thus, while the annual resources of recent immigrants would fall below the poverty line, the earliest immigrants appear to be much better situated.

The differences in annualized wealth by immigrant cohort could be reflecting differences in the age distribution of the earlier and more recent arrivals, with the more recent arrivals disproportionately populating the younger age brackets, which also tend to have lower annualized wealth levels. The differences in annualized wealth levels by years in the U.S., however, are large even within age brackets. Figure 3, for example, displays the median annualized wealth levels and composition of annualized wealth by years of arrival for married households with an oldest member aged 65-74. The chart indicates that annualized wealth falls dramatically with each subsequent cohort. In addition, the most 
recent arrivals hold virtually no financial wealth and have much less housing wealth than earlier immigrants and natives. The dramatic differences in annualized wealth within the 65-74 age group suggest that the gaps are unlikely to be due to differences in the age distribution of different immigrant arrival cohorts.

\subsection{Median Regressions of Annualized Wealth}

Of course, immigrants and natives may differ along a number of potentially important observable characteristics, including health, education, earnings, wealth, and expectations about longevity and bequests. In order to see whether levels of annualized wealth still differ between the groups after controlling for observables, we estimate median regressions of the logarithm of annualized wealth on key demographic and financial covariates for the sample of households married in the first wave in which they appear. These regressions are meant to be purely descriptive and should not be interpreted as implying causality. However, they will allow us to say something about whether the immigrant-native gap in annualized financial wealth can be fully accounted for by observable characteristics.

Table 4 reports weighted means for the covariates included in the regressions. The dependent variable in the regressions is the natural logarithm of annualized wealth. We control for immigration status with a set of immigration cohort dummies. Because we expect that the importance of marriage is likely to differ depending on whether the couple consists of two natives, two immigrants, or one immigrant and one native, we include dummies and interactions that control for each configuration. The annuitized, non-financial, and financial shares are within-household median shares of comprehensive wealth (see the notes to Table 1 for definitions of the three wealth components).

We include dummy variables for whether households report good health and whether they report fair or poor health (excellent/very good health is the omitted category, and we assign the household the less favorable of the respondent's and spouse's health status). We also include dummy variables for whether the respondent reported out-of-pocket health expenses in the second or third highest terciles of the expense distribution (where we again take the maximum tercile within the household). Finally, the bequest probability is an indicator variable that takes a value of 1 if respondents report that they will leave a bequest with a probability higher than $50 \%$. About half of the sample reports that they intend to leave a bequest with greater than even odds. 
In addition, we include variables from the restricted SSA earnings records and the restricted HRS geocode data. The restricted earnings data allow us to construct a variable for the average household covered earnings (in 2012 dollars) from 1951 to 2013. We include covariates for both the log of household earnings (plus one, to handle zeros) and the standard deviation of household earnings. The geocode data allow us to control for two additional variables of interest: whether respondents live in an urban area (defined as counties of metro areas with a population of 1 million or more) and respondents' countries of origin. We create indicators for countries of origin according to the World Bank's classification of income groups: low income $(\$ 1,035$ or less), lower middle income $(\$ 1,036$ to $\$ 4,085)$, upper middle income $(\$ 4,086$ to $\$ 12,615)$, and high income $(\$ 12,616$ or more). One of the challenges in working with the restricted geographic and Social Security data is that researchers are not allowed to merge the two sources of information. We therefore conduct separate analyses for the two data sources. Table 5 presents results from analysis with the restricted Social Security data, and Table 6 presents results from analysis with the restricted geographic data.

\subsubsection{Annualized wealth regressions: immigrants and natives}

Tables 5 and 6 report the coefficient estimates and standard errors for weighted median regressions of the natural log of annualized wealth on the covariates discussed above and a set of survey-year dummies, with standard errors clustered at the household level. Because we are interested in both the association of immigration status with annual wealth holding, as well as the channels through which that association might emerge, we present the estimates of four specifications that control for an increasing number of household characteristics.

The first specification ("Baseline") is sparse and includes only the immigrant cohort dummies and a pair of age dummies for the first and second half of retirement. The goal of the first specification is to examine the relationship between immigration status and annualized wealth without controlling for demographics, financial variables, or immigrant origins. The coefficient estimates on the cohort dummies indicate that immigrants hold less annualized wealth than natives and that their annualized wealth increases with years in the U.S. While the point estimate on the 1955-1964 cohort is small and statistically insignificant, the estimates on the three subsequent waves are all strongly significant and large in magnitude. The baseline results indicate that these three cohorts (1965-1974, 1975-1984, and 
$1985+)$ have $46 \%, 60 \%$, and $69 \%(=\exp (\hat{\beta})-1)$ less annualized wealth than immigrants, respectively. And as is true for all of the specifications, the pattern on the two age dummies (ages 70-79 and $80+$ ) is consistent with the upward-sloping profiles observed in Figure 2.

The second column (“+ Demographics”) adds basic demographic information such as race, education, family size, marital status, and number of children, as well as controls for citizenship, whether English is spoken in the home, and interactions for whether married couples consist of two immigrants or an immigrant and a native. While the marriage interactions are statistically insignificant in the "+ Demographics" specification, the estimate on the immigrant-married-to-immigrant dummy is negative and statistically significant in the final specification. The estimates suggest that being in a dual-immigrant marriage is associated with lower annualized wealth holdings of about $7 \%$. With the demographic controls, the coefficient estimates on the immigrant cohorts fall substantially, but those on the three most recent cohorts remain statistically significant at the $1 \%$ level. The estimates indicate that these cohorts have $13 \%, 25 \%$, and $48 \%$ less median annualized wealth, respectively.

The third column ("+ Life-cycle") controls for some of the key life-cycle variables that potentially shape wealth trajectories, including the shares of financial and non-financial wealth (measured at the first wave), the mean and standard deviation of log earnings (in the specifications using restricted SSA data), and controls for health, expected bequests, and expected longevity. While the first two columns of covariates were the same in Tables 5 and 6 , the third columns differ due to the fact that we are not allowed to merge restricted data on earnings and geography. Table 5 includes measures of the level and variation in lifetime earnings based on the restricted SSA data, while 6 introduces a control for whether households live in a highly populated urban area. In both specifications, the introduction of the life-cycle variables absorbs some of the association between immigration cohort and annualized wealth, particularly in in the case of the regression controlling for lifetime income. While the coefficient estimate on the most recent cohort falls (in absolute value) from -0.647 to -0.493 in the regression using the geocode data, the estimates fall (in absolute value) by an additional 2.4 percentage points-from 0.647 to -0.252 - when we control for lifetime earnings. These estimates suggest that much, but not all, of the differences in annualized wealth between the more recent cohorts and their native counterparts can be explained by lifecycle factors and by differences in their earnings histories.

The estimates on the shares of financial and non-financial wealth remain statistically significant 
across the different model specifications. A percentage point increase in the share of financial wealth is associated with about 1.6 percentage points more annualized wealth, and a percentage point increase in the share of non-financial wealth is associated with about 1 percentage points more annualized wealth. Without leaning too heavily on a causal interpretation of the finding, we note that this pattern of coefficient estimates is consistent with the predictions of a life-cycle model with housing. Households with relatively low levels of annuitized income (e.g., lower expected Social Security benefits relative to final earnings) have an incentive to build up more saving for retirement—both in order to maintain pre-retirement levels of consumption and also as a form of self-insurance against longevity risk.

The final columns of the regressions ("+ Origins") introduce interaction terms between immigrant status and race and ethnicity, as well as indicators for the country of origin (grouped according to the World Bank classification of incomes). Controlling for origins and immigrant race and ethnicity further dampens the coefficient estimates on the the 1965-1974 cohort dummy, but the estimates on the most recent immigrant cohort remain strongly negative and statistically significant. Thus, even after controlling for a rich set of observables, including lifetime earnings, geographic origins, and other life-cycle variables, a portion of the immigrant-native gap in annualized wealth remains unexplained for the most recent cohorts: with shortfalls in the range of 0-12\% for the 1975-1984 cohort and in the range of $15-33 \%$ for the most recent cohort (depending on whether we control for earnings or geocode information).

\subsubsection{Convergence of immigrant wealth?}

A central question in the labor literature is whether immigrant earnings tend to converge to those of natives with similar characteristics. If saving rates and asset allocation were held constant, convergence (divergence) in earnings would imply convergence (divergence) in retirement resources. Saving, however, involves a complex relationship between earnings, saving, financial investments, and house ownership. Therefore, convergence in earnings does not necessarily imply convergence in annualized wealth if saving and investment behavior differs systematically between immigrants and natives and across immigrant cohorts.

The results in Tables 5 and 6 suggest that the annualized resources of earlier immigrant waves are statistically indistinguishable from those of natives with similar characteristics. More recent immi- 
grant cohorts, however, appear to accumulate substantially less wealth heading into retirement. These results, however, implicitly assume that immigrants and natives share similar "returns" to household characteristics, such as family composition, financial variables, and health events.

It is possible that the negative coefficient estimates on the more recent immigrant cohorts could be picking up differences in the returns to characteristics between immigrants and natives. If this is the case, we would expect some of the wealth gradient by immigration wave to disappear if we regressed annualized wealth on the covariates of just immigrants. In Tables 7 and 8 , we report the estimates on an increasing set of covariates for a sample of immigrant households that consist either of single respondents or married couples where both members are immigrants. The omitted immigrant category is the pre-1955 cohort.

The coefficient estimates continue to show a pattern of decreasing annualized wealth with more recent cohorts. The one exception to the pattern is the 1955-1964 cohort, which actually appears to be better situated than the pre-1955 cohort, at least in the regressions using the restricted geographic sample (Table 8). The fact that this result does not hold in the regressions using restricted earnings information suggests that the 1955-1964 cohort may have benefited from higher average earnings over the life-cycle compared to the earliest immigrants. This makes sense given the post-War expansion in economic growth. Even controlling for earnings, however, the two most recent waves of immigrants show substantially lower wealth accumulation than the earlier waves. The 1975-1984 cohort holds 14 $17 \%$ lower annualized wealth than the earliest cohort, while the most recent wave has between $19 \%$ and $37 \%$ lower resources, depending on whether we use the restricted earnings or the restricted geographic sample.

\section{Conclusion}

This paper examines the total resources available to immigrants and natives in retirement. We find that wealth patterns differ substantially between the two groups, with a great deal of heterogeneity by socioeconomic and demographic characteristics. While immigrants have less wealth overall than natives, they appear to be decumulating resources in retirement at a slower rate. While any number of forces could explain the relative drawdown rates of households in the data, a relatively standard 
lifecycle framework points to the particular importance of a combination of home ownership and an explicit bequest motive. Maintaining higher levels of housing wealth late in the life cycle naturally leads to an increase in annual resources available to the household. But without a bequest motive, it is hard to explain why households would choose to maintain such high levels of housing at the cost of forgoing additional non-housing spending in retirement. The central importance of housing may also provide clues to the relatively slow drawdown rates of immigrant homeowners, who tend to have higher levels of home equity relative to natives.

The evidence so far suggests that the typical immigrant is relatively well situated in retirement, but that more recent immigrants have low levels of total resources and are likely to have difficulty maintaining adequate levels of spending in retirement. In this sense, the sample of households in the paper represents a potentially important transition point in the retirement well being of immigrants. The dramatic change in the composition of immigrants following the 1965 Immigration Act will soon be mirrored in the changing face of immigrant wealth in retirement. The results in the paper suggest that some of the newer immigrants are likely to be particularly vulnerable, arriving in retirement with a combination of low Social Security benefits, low private pension coverage, and insufficient financial and non-financial wealth. 


\section{References}

Anacker, K. B. 2013. Immigrating, Assimilating, Cashing in? Analyzing Property Values in Suburbs of Immigrant Gateways? Analyzing Property Values in Suburbs of Immigrant Gateways. Housing Studies 28(5): 720-745.

Blau, F. D., L. M. Kahn, J. Y. Moriarty, and A. P. Souza. 2003. The Role of the Family in Immigrants' Labor-Market Activity: An Evaluation of Alternative Explanations: Comment. The American Economic Review 93(1): 429-447.

Borjas, G. J. 1999. The Economic Analysis of Immigration. Handbook of labor economics 3: 16971760.

. 2002. Homeownership in the Immigrant Population. Journal of urban economics 52(3): 448476.

- 2010. Social Security Eligibility and the Labor Supply of Older Immigrants. Industrial and Labor Relations Review 64: 485.

Brown, J. R., and J. M. Poterba. 2000. Joint Life Annuities and Annuity Demand by Married Couples. The Journal of Risk and Insurance 67(4): 527-553.

Campbell, J. Y., and J. F. Cocco. 2007. How Do House Prices Affect Consumption? Evidence from Micro Data. Journal of Monetary Economics 54(3): 591-621.

Carroll, C. D. 1997. Buffer-Stock Saving and the Life Cycle/Permanent Income Hypothesis. The Quarterly Journal of Economics 112(1): 1-55.

— 2006. The Method of Endogenous Gridpoints for Solving Dynamic Stochastic Optimization Problems. Economics Letters 91(3): 312-320.

Carroll, C. D., B.-K. Rhee, and C. Rhee. 1994. Are There Cultural Effects on Saving? Some CrossSectional Evidence. The Quarterly Journal of Economics 109(3): 685-699.

1999. Does Cultural Origin Affect Saving Behavior? Evidence from Immigrants. Economic Development and Cultural Change 48(1): 33-50.

Chatterjee, S., and V. Zahirovic-Herbert. 2011. Homeownership and Housing Equity: An Examination of Native-Immigrant Differences in Housing Wealth. International Advances in Economic Research 17(2): 211-223.

Chen, K. 2010. A Life-Cycle Analysis of Social Security with Housing. Review of Economic Dynamics 13(3): 597-615.

Cobb-Clark, D. A., and V. A. Hildebrand. 2006. The Wealth and Asset Holdings of US-Born and Foreign-Born Households: Evidence from SIPP Data. Review of Income and Wealth 52(1): 17-42.

Cocco, J. F. 2005. Portfolio Choice in the Presence of Housing. Review of Financial Studies 18(2): $535-567$.

Cohen, L., and H. Iams. 2007. Income Adequacy and Social Security Differences Between the ForeignBorn and US-Born. International Migration Review 41(3): 553-578. 
Davis, M. A., and F. Ortalo-Magne. 2011. Household Expenditures, Wages, Rents. Review of Economic Dynamics 14(2): 248-261.

De Nardi, M., E. French, and J. B. Jones. 2015. Savings After Retirement: A Survey. Working Paper 21268, National Bureau of Economic Research.

Díaz, A., and M. J. Luengo-Prado. 2010. The Wealth Distribution with Durable Goods. International Economic Review 51(1): 143-170.

Drew, R. B. 2002. New Americans, New Homeowners: The Role and Relevance of Foreign Born Firsttime Homebuyers in the US Housing Market. Joint Center for Housing Studies, Graduate School of Design [and] John F. Kennedy School of Government, Harvard University.

Duleep, H. O., and D. J. Dowhan. 2008. Research on Immigrant Earnings. Soc. Sec. Bull. 68: 31.

Engen, E. M., W. G. Gale, and C. E. Uccello. 1999. The Adequacy of Household Saving. Brookings Papers on Economic Activity 1999(2): 65-187.

- 2005. Effects of Stock Market Fluctuations on the Adequacy of Retirement Wealth Accumulation. Review of Income and Wealth 51(3).

Favreault, M. M., and A. Nichols. 2011. Immigrant Diversity and Social Security: Recent Patterns and Future Prospects. Washington, DC: The Urban Institute.

Gervais, M. 2002. Housing Taxation and Capital Accumulation. Journal of Monetary Economics 49(7): 1461-1489.

Gustman, A. L., O. S. Mitchell, A. A. Samwick, and T. L. Steinmeier. 1997. Pension and Social Security Wealth in the Health and Retirement Study. NBER Working Paper No. W5912.

Gustman, A. L., and T. L. Steinmeier. 1999. Effects of Pensions on Savings: Analysis with Data from the Health and Retirement Study. Carnegie-Rochester Conference Series on Public Policy 50(0): $271-324$.

. 2000a. Pensions and Retiree Health Benefits in Household Wealth: Changes from 1969 to 1992. Journal of Human Resources 35(1): 30-50.

- 2000b. Social Security Benefits of Immigrants and US Born. In Issues in the Economics of Immigration, 309-350. University of Chicago Press.

Gustman, A. L., T. L. Steinmeier, and N. Tabatabai. 2009. What the Stock Market Decline Means for the Financial Security and Retirement Choices of the Near-Retirement Population. Tech. Rep., National Bureau of Economic Research.

- 2010. Pensions in the Health and Retirement Study. Harvard University Press.

Guvenen, F. 2007. Learning your Earning: Are Labor Income Shocks Really Very Persistent? The American economic review 687-712.

Haveman, R., K. Holden, B. Wolfe, and S. Sherlund. 2006. Do Newly Retired Workers in the United States Have Sufficient Resources to Maintain Well-Being? Economic Inquiry 44: 249-264. 
Heim, B. T., I. Z. Lurie, and S. P. Ramnath. 2012. Immigrant-Native Differences in Employment-Based Retirement Plan Participation. Journal of Pension Economics and Finance 11(3): 365.

Iacoviello, M., and M. Pavan. 2012. Housing and Debt over the Life Cycle and over the Business Cycle. Journal of Monetary Economics.

Iskhakov, F., J. Rust, and B. Schjerning. 2012. A Generalized Endogenous Grid Method for DiscreteContinuous Choice. Working Paper.

Kerr, S. P., and W. R. Kerr. 2013. Economic Impacts of Immigration: A Survey. Finnish Economic Papers 24(1): 1-32.

Kopecky, K. A., and R. M. Suen. 2010. Finite State Markov-Chain Approximations to Highly Persistent Processes. Review of Economic Dynamics 13(3): 701-714.

Lee, R., and T. Miller. 2000. Immigration, Social Security, and Broader Fiscal Impacts. The American Economic Review 90(2): 350-354.

Li, W., and R. Yao. 2007. The Life-Cycle Effects of House Price Changes. Journal of Money, Credit and Banking 39(6): 1375-1409.

Love, D. A. 2013. Optimal Rules of Thumb for Consumption and Portfolio Choice. The Economic Journal 123: 932-961.

Love, D. A., M. G. Palumbo, and P. A. Smith. 2009. The Trajectory of Wealth in Retirement. Journal of Public Economics 93(1): 191-208.

Love, D. A., P. A. Smith, and L. C. McNair. 2008. A New Look at the Wealth Adequacy of Older US Households. Review of Income and Wealth 54(4): 616-642.

Munnell, A. H., A. Webb, and L. Delorme. 2006. Retirements at Risk: A New National Retirement Index. Boston College Center for Retirement Research June.

Munnell, A. H., A. Webb, F. Golub-Sass, et al. 2012. The National Retirement Risk Index: An Update. Center for Retirement Research at Boston College 1.

Nakajima, M., and I. A. Telyukova. 2011. Home Equity in Retirement. Age 65(75): 85.

Osili, U. O., and A. L. Paulson. 2009. Immigrants' Access to Financial Services and Asset Accumulation. In Insufficient Funds, ed. Rebecca M. Blank and Michael S. Barr, 285-317. Russell Sage Foundation.

Poterba, J., S. Venti, and D. Wise. 2011. The Composition and Drawdown of Wealth in Retirement. Journal of Economic Perspectives 25(4): 95-118.

Poterba, J. M. 2015. Saver Heterogeneity and the Challenge of Assessing Retirement Saving Adequacy. National Tax Journal 68(2): 377.

Poterba, J. M., S. F. Venti, and D. A. Wise. 2012. Were They Prepared for Retirement? Investigations in the Economics of Aging 21.

Scholz, J. K., A. Seshadri, and S. Khitatrakun. 2006. Are Americans Saving "Optimally" for Retirement? Journal of Political Economy 114(4): 607-643. 
Sevak, P., and L. Schmidt. 2008. Immigrant-Native Fertility and Mortality Differentials in the United States. Michigan Retirement Research Center WP 2008-181.

— 2014. Immigrants and Retirement Resources. Social Security Bulletin 74(1).

Shiller, R. J. 2005. Irrational Exuberance. Princeton University Press.

Sierminska, E., P.-C. Michaud, and S. Rohwedder. 2008. Measuring Wealth Holdings of Older Households in the U.S.: A Comparison using the HRS, PSID and SCF. RAND Working Paper.

Smith, J. P. 1995. Racial and Ethnic Differences in Wealth in the Health and Retirement Study. Journal of Human Resources 30(Special Issue on the Health and Retirement Study: Data Quality and Early Results): S158-S183.

Smith, K. E., M. Soto, and R. G. Penner. 2009. How Seniors Change Their Asset Holdings During Retirement. The Retirement Policy Program: Discussion Paper 09-06.

SSA. 2010. The 2010 Annual Report of the Board of Trustees of the Federal Old-Age and Survivors Insurance and Disability Insurance Trust Funds. Social Security Administration.

Storesletten, K. 2000. Sustaining Fiscal Policy Through Immigration. Journal of Political Economy 108(2): 300-323.

VanDerhei, J., and C. Copeland. 2010. The EBRI retirement readiness rating:TM Retirement income preparation and future prospects. EBRI Issue Brief 1(344).

Wolff, E. N. 2007. The Retirement Wealth of the Baby Boom Generation. Journal of Monetary Economics 54(1): 1-40.

Yang, F. 2009. Consumption over the Life Cycle: How Different Is Housing? Review of Economic Dynamics 12(3): 423-443.

Yao, R., and H. H. Zhang. 2005. Optimal Consumption and Portfolio Choices with Risky Housing and Borrowing Constraints. Review of Financial Studies 18(1): 197-239. 


\section{Appendix: Details and Solution of Life Cycle Model}

Households in the model start their working lives at age 20, retire at age 65, and live to a maximum of 100. Before age 100, individuals survive from one period to the next with probabilities, $\varsigma_{t}$, taken from the 2007 SSA Period Life Table. During the working life, households supply labor inelastically and face persistent productivity shocks. In retirement, they receive a fraction of final earnings in Social Security benefits. Conditional on final earnings, retirement income is risk-free, though in some specifications we introduce risky income in retirement as a proxy for medical expense uncertainty. The problem facing the household is to choose consumption, housing, and rental services in the face of uncertain income and mortality.

\subsubsection{Housing}

Each period, households choose whether to own or rent. If they rent, they are free to choose a continuous level of rental housing at price $p$. Homeowners enter each period knowing their current house value, $H_{t}$, which they cannot change until the subsequent period. If they do change their stock of owned housing, they incur an transactions cost based on the value of the house sale (if any): $\tau H_{t}$. While households can choose among a continuous set of rental houses, the stock of houses available for purchase or sale is discrete, so that $H_{t+1} \in\left[0, H^{1}, H^{2}, \ldots, H^{n}\right]{ }^{15}$ We abstract from modeling house price fluctuations and assume zero growth in real house prices ${ }^{16}$

As in Iacoviello and Pavan (2012), the maximum amount households can borrow depends both on the value of housing and on the present value of income. Households can borrow no more than $L=$ $\min \left(\theta^{H} H_{t+1} / R, \theta^{Y} F Y_{t}\right)$, where $F Y_{t}$ denotes the expected present value of lifetime income, and $\theta^{H}$ and $\theta^{Y}$ are parameters governing the credit limits on housing and income ${ }^{17} \|^{8}$ We make the credit constraint a function of the present value of future income to capture the income requirements associated with mortgage lending. In order to avoid carrying around an additional state variable for the size of mortgage borrowing, we assume that households leverage up to the limit.

\footnotetext{
${ }^{15}$ The assumption that households can choose among a continuous set of rental units but only a discrete set of houses greatly simplifies the numerical solution to the model. The fact that rental housing is continuous means that we can pin down the optimal renting decision from the first order conditions of consumption and housing services. The discrete nature of owned housing, in contrast, allows us to solve the model using the generalized endogenous grid points method in Iskhakov et al. (2012).

${ }^{10}$ The zero growth assumption is actually consistent with the Case-Shiller housing price index from 1890-2013, which imply an average annual growth rate in real house prices of about $0.2 \%$ (Shiller. 2005). The decision not to model house price volatility is motivated by simplicity and the fact that the added complexity would be unlikely to affect the main mechanism of the model, which operates through credit constraints, transactions costs, and the cost advantage of ownership over rental housing.

${ }^{17}$ In contrast to Iacoviello and Pavan (2012), we discount future income streams not only by the interest rate, but also by the relevant unconditional survival probabilities, $\Psi_{t}$. The expected discounted value of income is given by: $F V_{t}=E_{t} \sum_{i=0}^{T-t} \Psi_{t+i} Y_{t+i} R^{-i}$.

${ }^{18}$ Suppose, for example, that in period $t$ a household decides to purchase a house for the first time in period $t+1$ and takes out the maximum amount of debt against the value of the house (assuming the income credit constraint is non-binding). The bank will lend $\theta^{H}$ fraction of the house value. In order to make the timing of the house purchase and the loan consistent, we assume that the household takes out a present value mortgage of $\theta^{H} H_{t+1} / R$ in period $t$, which it puts toward the purchase of the present value of the house next period, $H_{t+1} / R$, where $R$ is the risk-free gross rate of return. In this formulation, if the credit constraint binds, the household will carry $-\theta^{H} H_{t+1}$ of savings (equal to the negative mortgage balance) into the beginning of the next period.
} 


\subsubsection{Preferences}

Preferences are a Cobb-Douglas aggregate of consumption, $C_{t}$, and housing services, $S_{t}$ :

$$
U\left(C_{t}, S_{t}\right)=\frac{1}{1-\gamma}\left(C_{t}^{1-\alpha} S_{t}^{\alpha}\right)^{1-\gamma}
$$

and bequests are given by:

$$
B_{t}\left(W_{t}\right)=\frac{b}{1-\gamma}\left(\frac{W_{t}}{b}\right)^{1-\gamma}
$$

where $W_{t}=X_{t}+H_{t}$ is the net worth of the household at the point of death.

\subsubsection{Income}

Log income during the working life evolves according to:

$$
\ln \left(Y_{t}\right)=f\left(\text { age }_{t}\right)+v_{t},
$$

where $f\left(a g e_{t}\right)$ captures the exogenous age efficiency profile, and $v_{t}$ follows a Markov process:

$$
v_{t}=\rho v_{t-1}+\varepsilon_{t}, \varepsilon_{t} N\left(0, \sigma_{\varepsilon}^{2}\right) .
$$

In retirement, households receive Social Security benefits equal to a fraction $\lambda$ of final-period earnings. Retirement income is uncertain from the perspective of working-age households, but it is certain once the final earnings shock has been realized. In some specifications, we model retirement risk by assuming that income follows the same AR(1) process for the entire life cycle.

\section{Solution}

The problem facing the household can be summarized in the following value function:

$$
\begin{aligned}
V_{t}\left(X_{t}, H_{t}, Y_{t}\right)=\max _{C_{t}, S_{t}, H_{t+1}}\left\{U\left(C_{t}, S_{t}\right)+\beta \varsigma_{t} E_{t} V_{t+1}\left(X_{t+1}, H_{t+1}, Y_{t+1}\right)\right. \\
\left.+\beta\left(1-\varsigma_{t}\right) E_{t} B_{t+1}\left(X_{t+1}+H_{t+1}\right)\right\} .
\end{aligned}
$$

such that:

$$
\begin{aligned}
X_{t+1} & =A_{t} R+Y_{t+1} \\
A_{t} & =X_{t}-C_{t}-S_{t} p-\left[H_{t+1}-\left(1-\delta^{H}\right) H_{t}+\tau I_{H} H_{t}\right] / R \\
A_{t} & \geq-L=\min \left(\theta^{H} H_{t+1} / R, \theta^{Y} F Y_{t}\right),
\end{aligned}
$$

where $R$ is the gross risk-free rate of return, $A_{t}$ is end-of-period saving net of housing, $I_{H}$ is an indicator for whether there is a house sale, and $Y_{t+1}=0$ in the event of death. $A_{t}$ plays a crucial role in the solution method of the problem. The usual formulation of end-of-period housing is cash on hand less consumption. Our modified definition accounts for the cost of rental housing, as well as the present value change in the stock of housing. The advantage of formulating the problem this way is that it allows us to take advantage of the endogenous grid point method pioneered by Carroll (2006) and 
extended to handle the case of a discrete choice variable by Iskhakov et al. (2012) 19

The solution method takes advantage of the fact that consumption Euler condition will hold for a given discrete choice of $H_{t+1}$ so long as there are no binding constraints ${ }^{20}$ Given the set of incoming state variables, we solve for the optimal levels of consumption and the value functions for the full set of $H_{t+1}$ values. The value function for that period is then the upper envelope of the $n_{h}+1$ (the discrete house values plus the renting state) value functions associated with each $H_{t+1}$.

In the case of homeowners, the first-order condition for consumption is:

$$
U_{t}^{c}=\beta \varsigma_{t} E_{t} R V_{t+1}^{x}+\beta\left(1-\varsigma_{t}\right) E_{t} R B_{t+1}^{\prime}
$$

where we have omitted the function arguments for ease of reading. Applying the envelope condition, we have:

$$
U_{t}^{c}=\beta \varsigma_{t} E_{t} R U_{t+1}^{c}+\beta\left(1-\varsigma_{t}\right) E_{t} R B_{t+1}^{\prime}
$$

The problem for renters is similar, with the only difference being that the lefthand side of the Euler equation is evaluated at the optimal level of rental housing. Given the Cobb-Douglas aggregator of consumption and housing services in the utility function, rental services must satisfy:

$$
S_{t}=\frac{\alpha C_{t}}{p(1-\alpha)}
$$

For each period $T$ housing state, we solve the final period's problem for a discrete range of end-ofperiod saving values, $A_{T}$, and we use $A_{T}=X_{T}-C_{T}-p S_{T}+\left(1-\delta^{H}-\tau\right) H_{T}$ to recover endogenous cash on hand, given optimal choices of $C_{T}$ and $S_{T}$. For all periods $t<T$, we use the first order conditions A-9 and A-10 to solve for optimal consumption and rental housing services (for non-owners) for all discrete combinations of $H_{t}$ and $H_{t+1}$. For each value of $H_{t}$, we solve for the optimal choice of $H_{t+1}$ by taking the upper envelope of the value function over next period's housing decisions. This yields decision rules for consumption, renting, and housing choices that we can use to recover $X_{t}$, given the constraint $\mathrm{A}-6){ }^{21}$

\subsection{Parameterization}

Given that our primary interest in the model is to understand the qualitative implications of housing, risk, and bequests for annualized wealth paths, we adopt a relatively standard parameterization of the model. We set the discount factor $\beta$ to 0.97 , the real risk-free interest rate (on borrowing and lending) to $3 \%$, the coefficient of relative risk aversion to 3 , and the bequest parameter, $b$ to 2 . We set the CobbDouglas expenditure share of housing to 0.25 , which is equal to the average value of rental expenditure shares across the 50 largest U.S. MSAs (Davis and Ortalo-Magne, 2011). As noted in the main text, we take the survival probabilities from the Social Security Administration's 2007 Period Life Tables.

\footnotetext{
${ }^{19}$ The advantage of the endogenous grid point method comes from the fact that it allows us to solve for optimal consumption by inverting the righthand side of the consumption Euler equation instead of using computationally expensive root-finding techniques to solve for the first order condition. The key "trick" that allows us to adopt Iskhakov et al. (2012) is the redefinition of end-of-period savings to include housing.

${ }^{20}$ The result may seem surprising, since the value function will generally have kinks caused by changes in the optimal choices of $H_{t}$ in future periods. As Iskhakov et al.(2012) explain, however, the intuition for the result stems from the fact that the kinks in the value function will necessarily be downward pointing, which implies that these kinks cannot be candidate optima and that the solution must therefore satisfy the Euler equation with respect to the continuous variable.

${ }^{21}$ The Matlab code is available from the authors upon request.
} 
In terms of the income process, we set the AR(1) coefficient to 0.97 and the standard error of the persistent component of earnings to 0.12 , which is well within the range of previous estimates of AR(1) income processes (see Guvenen, 2007). We approximate the earnings process using the (7-point, in our case) Rouwenhorst finite-state Markov chain described in Kopecky and Suen (2010). The earnings profiles and retirement-income-to-earnings ratios are taken from Love (2013), who estimates profiles using post-government income data from the 1980-2007 years of the PSID.

We solve the model for 20 discrete housing values, which are evenly spaced between $\$ 100,000$ and $\$ 800,000$. We assume that owned houses depreciate at a rate of $1.5 \%$, while rental units depreciate at a rate of $3 \%$, reflecting information asymmetries in the rental market. For the majority of our specifications, we set the borrowing limit, $\theta$ to $80 \%$, which corresponds to the average downpayment ratio (20\%) on U.S. mortgages (Chen, 2010). Finally, we assume that the transactions costs on both buying and selling are $6 \%$, which is a typical fee charged by real estate agents and in line with the values assumed in the literature on life-cycle housing (see Yang, 2009). 


\section{Tables and Figures}

Table 1

Comprehensive Wealth Components (in 1000s of Year-2012 Dollars)

\begin{tabular}{|c|c|c|c|c|c|c|c|c|c|}
\hline & & \multicolumn{8}{|c|}{ Means } \\
\hline & & \multicolumn{2}{|c|}{ Financial } & \multicolumn{2}{|c|}{ Non-Financial } & \multicolumn{2}{|c|}{ Social Security } & \multicolumn{2}{|c|}{ Comprehensive } \\
\hline \multirow{3}{*}{ Married } & Age & Immigrant & Native & Immigrant & Native & Immigrant & Native & Immigrant & Native \\
\hline & $65-74$ & 378 & 390 & 475 & 417 & 322 & 406 & 1,407 & 1,630 \\
\hline & $75-85$ & 271 & 349 & 342 & 384 & 221 & 258 & 1,007 & 1,246 \\
\hline \multirow[t]{2}{*}{ Single female } & $65-74$ & 89 & 117 & 161 & 148 & 124 & 174 & 449 & 533 \\
\hline & $75-85$ & 47 & 126 & 146 & 180 & 93 & 116 & 324 & 483 \\
\hline \multirow[t]{4}{*}{ Single male } & $65-74$ & 174 & 221 & 236 & 275 & 157 & 181 & 639 & 1,043 \\
\hline & $75-85$ & 224 & 219 & 274 & 224 & 98 & 114 & 635 & 644 \\
\hline & & \multicolumn{8}{|c|}{ Medians } \\
\hline & & \multicolumn{2}{|c|}{ Financial } & \multicolumn{2}{|c|}{ Non-Financial } & \multicolumn{2}{|c|}{ Social Security } & \multicolumn{2}{|c|}{ Comprehensive } \\
\hline & Age & Immigrant & Native & Immigrant & Native & Immigrant & Native & Immigrant & Native \\
\hline Married & $65-74$ & 11 & 112 & 163 & 197 & 306 & 395 & 685 & 1,169 \\
\hline & $75-85$ & 16 & 108 & 160 & 188 & 212 & 238 & 581 & 838 \\
\hline Single female & $65-74$ & 0 & 11 & 13 & 68 & 115 & 164 & 200 & 338 \\
\hline & $75-85$ & 1 & 16 & 5 & 77 & 88 & 109 & 160 & 281 \\
\hline Single male & $65-74$ & 1 & 26 & 20 & 82 & 148 & 176 & 240 & 439 \\
\hline & $75-85$ & 10 & 38 & 27 & 88 & 93 & 108 & 246 & 346 \\
\hline
\end{tabular}

This table reports weighted means and medians of comprehensive wealth categories in the 1998-2012 waves of the HRS for households with a respondent or spouse aged 51 or older. The light gray shaded regions indicate that the means or medians for immigrants and natives are not significantly different at the 5\% level. The means are compared using a weighted t-test. The medians are compared using a Pearson chi-squared test. Financial wealth is the sum of stocks, bonds, checking accounts, CDs, Treasuries, and other financial assets, including retirement plan assets (DC pensions, IRA, and Keogh Plans), less non-vehicle and non-housing debts. Non-financial wealth is the sum of housing, vehicles, and investment and business real estate less associated debt. Social Security is the actuarial present discounted value of current and expected Social Security benefits. Comprehensive wealth is the sum of all financial, non-financial, and present-value wealth sources, excluding future wage payments (see text for details). An "immigrant" household is defined as one in which the respondent and spouse (if present) were born in a country other than the U.S. A "native" household is defined as one in which the respondent and spouse (if present) were born in the U.S. In the case of married households, "Age" is the maximum age of the respondent and spouse. 
Table 2

Annualized Wealth: Levels and Growth within $\pm 25 \%$ of the Median

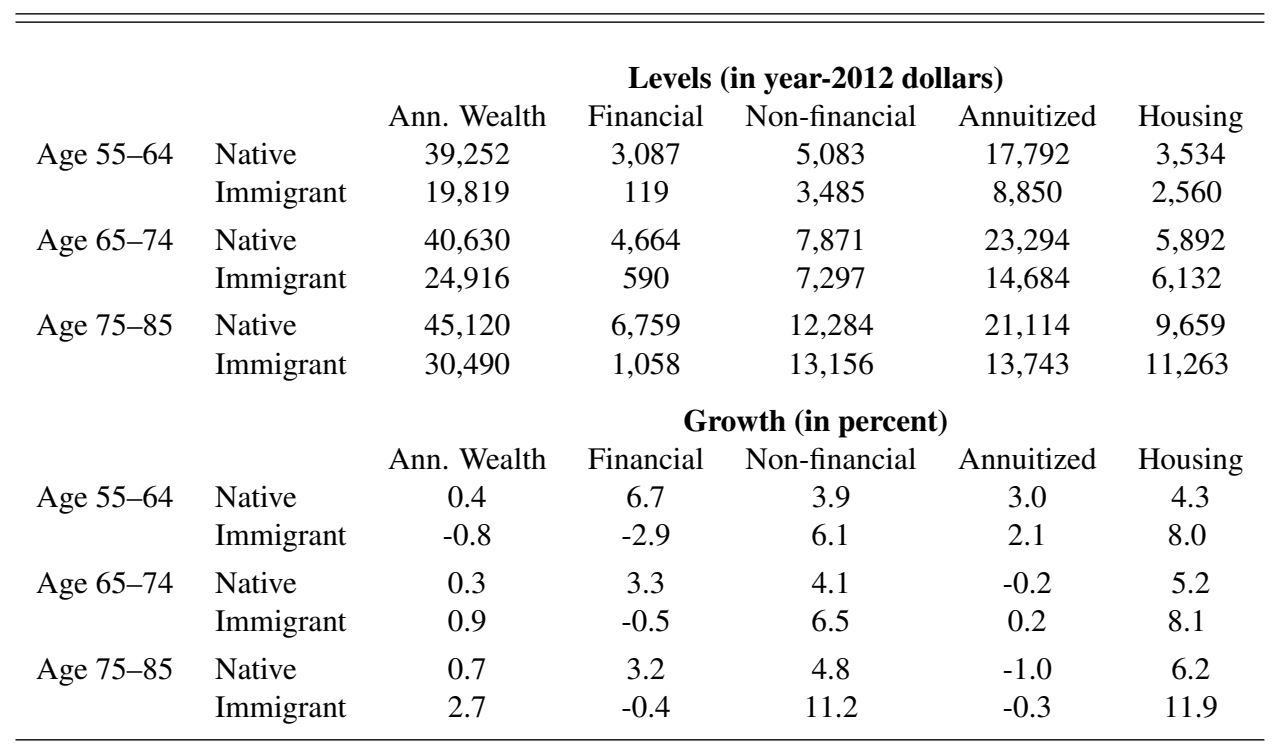

This table reports the median levels and growth rates of various components of annualized wealth for households who were married in the first wave of the sample period. All entries in the table show median values for households holding annualized comprehensive wealth within a band of $\pm 25 \%$ of the year-specific median annualized wealth for that group (e.g., natives aged 65-74). Financial wealth sums stocks, bonds, checking accounts, CDs, Treasuries, and other financial assets, including retirement plan assets, less non-vehicle and non-housing debts. Non-financial wealth is the sum of housing, vehicles, and investment and business real estate less associated debt. Annuitized wealth includes the actuarial present discounted value of Social Security, DB pensions, as well as other regular income payments such as veteran's benefits, food stamps, and SSI. Housing is the net value of the first and second residence plus any mobile homes. The growth rates are the median annual growth rates within households across time with positive holdings of each wealth category. 
Table 3

Annualized Comprehensive Wealth by Demographic Category (in 1000s of Year-2012 Dollars)

\begin{tabular}{|c|c|c|c|c|c|}
\hline & & \multicolumn{4}{|c|}{ Mean Annualized Wealth } \\
\hline & & \multicolumn{2}{|c|}{ Ages $65-74$} & \multicolumn{2}{|c|}{ Ages $75-85$} \\
\hline & & Immigrant & Native & Immigrant & Native \\
\hline \multirow[t]{3}{*}{ Education } & $<$ High School & 26.8 & 32.8 & 46.0 & 39.6 \\
\hline & High School & 41.1 & 50.5 & 52.0 & 63.4 \\
\hline & College & 104.0 & 99.8 & 85.7 & 125.0 \\
\hline \multirow[t]{3}{*}{ Race } & White & 85.6 & 63.0 & 89.1 & 75.6 \\
\hline & Nonwhite & 64.9 & 33.7 & 39.0 & 34.9 \\
\hline & Hispanic & 19.4 & 36.7 & 22.4 & 43.4 \\
\hline \multirow[t]{8}{*}{ Immigrant Cohort } & Pre-1955 & 48.9 & . & 61.7 & . \\
\hline & 1955-1964 & 84.2 & . & 81.8 & 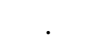 \\
\hline & $1965-1974$ & 40.8 & . & 49.9 & 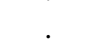 \\
\hline & 1975-1984 & 29.3 & . & 38.5 & . \\
\hline & $1985+$ & 15.4 & . & 9.5 & 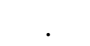 \\
\hline & & \multicolumn{4}{|c|}{ Median Annualized Wealth } \\
\hline & & \multicolumn{2}{|c|}{ Ages $65-74$} & \multicolumn{2}{|c|}{ Ages $75-85$} \\
\hline & & Immigrant & Native & Immigrant & Native \\
\hline \multirow[t]{3}{*}{ Education } & $<$ High School & 15.4 & 22.2 & 19.9 & 27.2 \\
\hline & High School & 30.0 & 39.3 & 30.2 & 46.1 \\
\hline & College & 55.2 & 73.4 & 55.8 & 86.6 \\
\hline \multirow[t]{3}{*}{ Race } & White & 47.7 & 44.1 & 68.0 & 48.6 \\
\hline & Nonwhite & 31.7 & 23.0 & 19.0 & 23.1 \\
\hline & Hispanic & 15.1 & 26.7 & 14.1 & 28.0 \\
\hline \multirow[t]{5}{*}{ Immigrant Cohort } & Pre-1955 & 34.0 & . & 33.4 & . \\
\hline & 1955-1964 & 38.0 & . & 55.8 & . \\
\hline & 1965-1974 & 24.0 & . & 30.9 & . \\
\hline & 1975-1984 & 14.4 & . & 18.1 & . \\
\hline & $1985+$ & 8.8 & . & 7.6 & . \\
\hline
\end{tabular}

This table displays the mean and median values of comprehensive wealth in the 1998-2012 waves of the HRS for households who were married in the first wave they appeared in the sample. "Native" married couples consist of two natives, and "Immigrant" married couples consist of two immigrants. Annualized comprehensive wealth is the annual income derived from an actuarially fair joint-life annuity purchased with the household's full value of comprehensive wealth. All means and medians for immigrants and natives are significantly different at the $5 \%$ level. The means are compared using a weighted t-test. The medians are compared using a Pearson chi-squared test. See the footnote to Table 1 for the definition of immigrant status and age. 
Table 4

Descriptive Statistics

\begin{tabular}{lcccc} 
Variable & Mean & Std. Dev. & Min & Max \\
\hline Log annualized wealth & 10.42 & 0.88 & 1.68 & 15.66 \\
Immigrant & 0.09 & 0.28 & 0.00 & 1.00 \\
Immigrated pre-1955 & 0.02 & 0.13 & 0.00 & 1.00 \\
Immigrated 1955-1964 & 0.02 & 0.13 & 0.00 & 1.00 \\
Immigrated 1965-1974 & 0.02 & 0.14 & 0.00 & 1.00 \\
Immigrated 1975-1984 & 0.02 & 0.13 & 0.00 & 1.00 \\
Immigrated 1985+ & 0.01 & 0.10 & 0.00 & 1.00 \\
Naturalized citizen & 0.06 & 0.23 & 0.00 & 1.00 \\
No English & 0.03 & 0.17 & 0.00 & 1.00 \\
Ages 65-74 & 0.25 & 0.43 & 0.00 & 1.00 \\
Ages 75+ & 0.23 & 0.42 & 0.00 & 1.00 \\
Married & 0.50 & 0.50 & 0.00 & 1.00 \\
Immigrant Married to Immigrant & 0.03 & 0.17 & 0.00 & 1.00 \\
Immigrant Married to Native & 0.03 & 0.18 & 0.00 & 1.00 \\
High School & 0.54 & 0.50 & 0.00 & 1.00 \\
College & 0.26 & 0.44 & 0.00 & 1.00 \\
Hispanic & 0.07 & 0.26 & 0.00 & 1.00 \\
Non-white & 0.13 & 0.34 & 0.00 & 1.00 \\
Family size & 2.13 & 1.22 & 1.00 & 19.00 \\
Num. of children & 2.91 & 2.03 & 0.00 & 22.00 \\
Share Financial & 0.13 & 0.63 & -94.96 & 22.36 \\
Share Non-financial & 0.22 & 0.76 & -138.55 & 48.53 \\
Log of average household earnings & 11.06 & 5.74 & 0.00 & 15.91 \\
Std. of log household earnings & 0.92 & 0.33 & 0.01 & 3.01 \\
Good health & 0.34 & 0.47 & 0.00 & 1.00 \\
Fair/poor health & 0.34 & 0.48 & 0.00 & 1.00 \\
Med OOP costs & 0.34 & 0.47 & 0.00 & 1.00 \\
High OOP costs & 0.30 & 0.46 & 0.00 & 1.00 \\
Pr(Bequest) $>$ 50\% & 0.44 & 0.50 & 0.00 & 1.00 \\
Hispanic immigrant & 0.04 & 0.19 & 0.00 & 1.00 \\
Nonwhite immigrant & 0.02 & 0.13 & 0.00 & 1.00 \\
\hline & & & \\
& & & &
\end{tabular}

This table reports descriptive statistics for the 1998-2012 waves of the HRS for households with a respondent or spouse aged 51 or older. The natural logarithm of financial wealth, as well as the shares of financial and nonfinancial wealth, are the initial values observed within the panel for each household. The years in the U.S. is the average years in the U.S. within the household. Education categories pertain to the respondent. Family size is the number of people living in the household at the time of the survey. "Good health" and "Fair/poor health" are indicator variables for self-reported health status ("excellent/very good" is the omitted category). "Med OOP costs" and "High OOP costs" are indicators for the highest $1 / 3$ percentiles of out-of-pocked medical costs (the lowest $1 / 3$ percentile is omitted). The bequest probability is an indicator variable for whether respondents report that they expect to leave a bequest with a probability greater than $50 \%$. 
Table 5

Median Regressions of Log Annualized Wealth, Restricted Earnings Data

\begin{tabular}{|c|c|c|c|c|}
\hline & Baseline & + Demographics & + Life-cycle & + Immigrant Race \\
\hline \multirow[t]{2}{*}{ Immigrated pre-1955 } & $-0.159 *$ & -0.045 & 0.044 & $0.094 * *$ \\
\hline & $(0.094)$ & $(0.065)$ & $(0.046)$ & $(0.043)$ \\
\hline \multirow[t]{2}{*}{ Immigrated 1955-1964 } & -0.101 & 0.010 & 0.039 & $0.112^{* * * *}$ \\
\hline & $(0.069)$ & $(0.059)$ & $(0.047)$ & $(0.041)$ \\
\hline \multirow[t]{2}{*}{ Immigrated 1965-1974 } & $-0.618 * * *$ & $-0.139 * * *$ & -0.034 & 0.060 \\
\hline & $(0.085)$ & $(0.052)$ & $(0.036)$ & $(0.044)$ \\
\hline \multirow[t]{2}{*}{ Immigrated 1975-1984 } & $-0.920 * * *$ & $-0.286^{* * * *}$ & $-0.134 * * *$ & -0.040 \\
\hline & $(0.061)$ & $(0.052)$ & $(0.042)$ & $(0.055)$ \\
\hline \multirow[t]{2}{*}{ Immigrated $1985+$} & $-1.184 * * *$ & $-0.647 * * *$ & $-0.252 * * *$ & $-0.170 * * *$ \\
\hline & $(0.074)$ & $(0.074)$ & $(0.049)$ & $(0.055)$ \\
\hline \multirow{2}{*}{ Ages $65-74$} & $0.085 * * *$ & $0.154 * * *$ & $0.033 *$ & $0.032 *$ \\
\hline & $(0.014)$ & $(0.010)$ & $(0.017)$ & $(0.017)$ \\
\hline \multirow[t]{2}{*}{ Ages $75+$} & $0.192 * * *$ & $0.341 * * *$ & $0.143^{* * *}$ & $0.143^{* * *} *$ \\
\hline & $(0.019)$ & $(0.014)$ & $(0.034)$ & $(0.034)$ \\
\hline \multirow[t]{2}{*}{ Married } & & $0.300 * * *$ & $0.091 * * *$ & $0.093^{* * *}$ \\
\hline & & $(0.013)$ & $(0.012)$ & $(0.012)$ \\
\hline \multirow[t]{2}{*}{ Immigrant Married to Immigrant } & & 0.038 & $-0.097 * * *$ & $-0.071 * *$ \\
\hline & & $(0.041)$ & $(0.033)$ & $(0.035)$ \\
\hline \multirow[t]{2}{*}{ Immigrant Married to Native } & & 0.030 & 0.032 & 0.015 \\
\hline & & $(0.037)$ & $(0.027)$ & $(0.029)$ \\
\hline \multirow[t]{2}{*}{ Naturalized citizen } & & $0.075^{*}$ & 0.020 & 0.025 \\
\hline & & $(0.044)$ & $(0.031)$ & $(0.031)$ \\
\hline \multirow[t]{2}{*}{ No English } & & $-0.167 * * *$ & $-0.104 * * *$ & $-0.084 * *$ \\
\hline & & $(0.041)$ & $(0.037)$ & $(0.037)$ \\
\hline \multirow{2}{*}{ High School } & & $0.495 * * *$ & $0.221 * * *$ & $0.224 * * *$ \\
\hline & & $(0.015)$ & $(0.020)$ & $(0.020)$ \\
\hline \multirow[t]{2}{*}{ College } & & $1.102 * * *$ & $0.603 * * *$ & $0.604 * * *$ \\
\hline & & $(0.019)$ & $(0.042)$ & $(0.041)$ \\
\hline \multirow[t]{2}{*}{ Hispanic } & & $-0.455 * * *$ & $-0.219 * * *$ & $-0.165 * * *$ \\
\hline & & $(0.030)$ & $(0.028)$ & $(0.032)$ \\
\hline Non-white & & $-0.418 * * *$ & $-0.153 * * *$ & $-0.152 * * *$ \\
\hline & & $(0.017)$ & $(0.026)$ & $(0.025)$ \\
\hline Family size & & $-0.029 * * *$ & -0.003 & -0.002 \\
\hline & & $(0.005)$ & $(0.004)$ & $(0.004)$ \\
\hline Num. of children & & $-0.023 * * *$ & $-0.008 * * *$ & $-0.008 * * *$ \\
\hline & & $(0.003)$ & $(0.002)$ & $(0.002)$ \\
\hline Share Financial & & & $0.016 * * *$ & $0.016 * * *$ \\
\hline & & & $(0.003)$ & $(0.003)$ \\
\hline Share Non-financial & & & $0.010 * * *$ & $0.010 * * *$ \\
\hline & & & $(0.001)$ & $(0.001)$ \\
\hline Log of average household earnings & & & $0.108 * * *$ & $0.107 * * *$ \\
\hline & & & $(0.007)$ & $(0.007)$ \\
\hline Std. of log household earnings & & & $0.033^{* *}$ & $0.034 * *$ \\
\hline & & & $(0.016)$ & $(0.016)$ \\
\hline Good health & & & $-0.070 * * *$ & $-0.071 * * *$ \\
\hline & & & $(0.011)$ & $(0.012)$ \\
\hline Fair/poor health & & & $-0.188 * * *$ & $-0.187 * * *$ \\
\hline & & & $(0.017)$ & $(0.018)$ \\
\hline Med OOP costs & & & $0.095 * * *$ & $0.096 * * *$ \\
\hline & & & $(0.009)$ & $(0.009)$ \\
\hline High OOP costs & & & $0.096 * * *$ & $0.097 * * *$ \\
\hline & & & $(0.012)$ & $(0.013)$ \\
\hline $\operatorname{Pr}($ Bequest $)>50 \%$ & & & $0.207 * * *$ & $0.206 * * *$ \\
\hline & & & $(0.016)$ & $(0.016)$ \\
\hline Hispanic immigrant & & & & $-0.186 * * *$ \\
\hline & & & & $(0.043)$ \\
\hline Nonwhite immigrant & & & & $-0.093^{*}$ \\
\hline & & & & $(0.049)$ \\
\hline Constant & $10.329 * * *$ & $9.876^{* * *}$ & $8.121 * * *$ & $8.132^{* * * *}$ \\
\hline & $(0.010)$ & $(0.020)$ & $(0.082)$ & $(0.081)$ \\
\hline R-squared & 0.059 & 0.370 & 0.093 & 0.093 \\
\hline Obs. & 105278 & 103255 & 81115 & 81115 \\
\hline
\end{tabular}

This table reports coefficient estimates and standard errors from qubltile regressions of the natural logarithm annualized wealth on household characteristics for households with respondents aged 51 or older in the 1998 2012 waves of the HRS. All specifications include a full set of year dummies. The HRS data were merged with restricted earnings records from the SSA. See the note under Table 4 and the main text for definitions and a discussion of the covariates. Standard errors are clustered at the household level. Asterisks denote levels of statistical significance: $* p<0.10, * * p<0.05, * * * p<0.01$. 
Table 6

Median Regressions of Log Annualized Wealth, Restricted Geocode Data

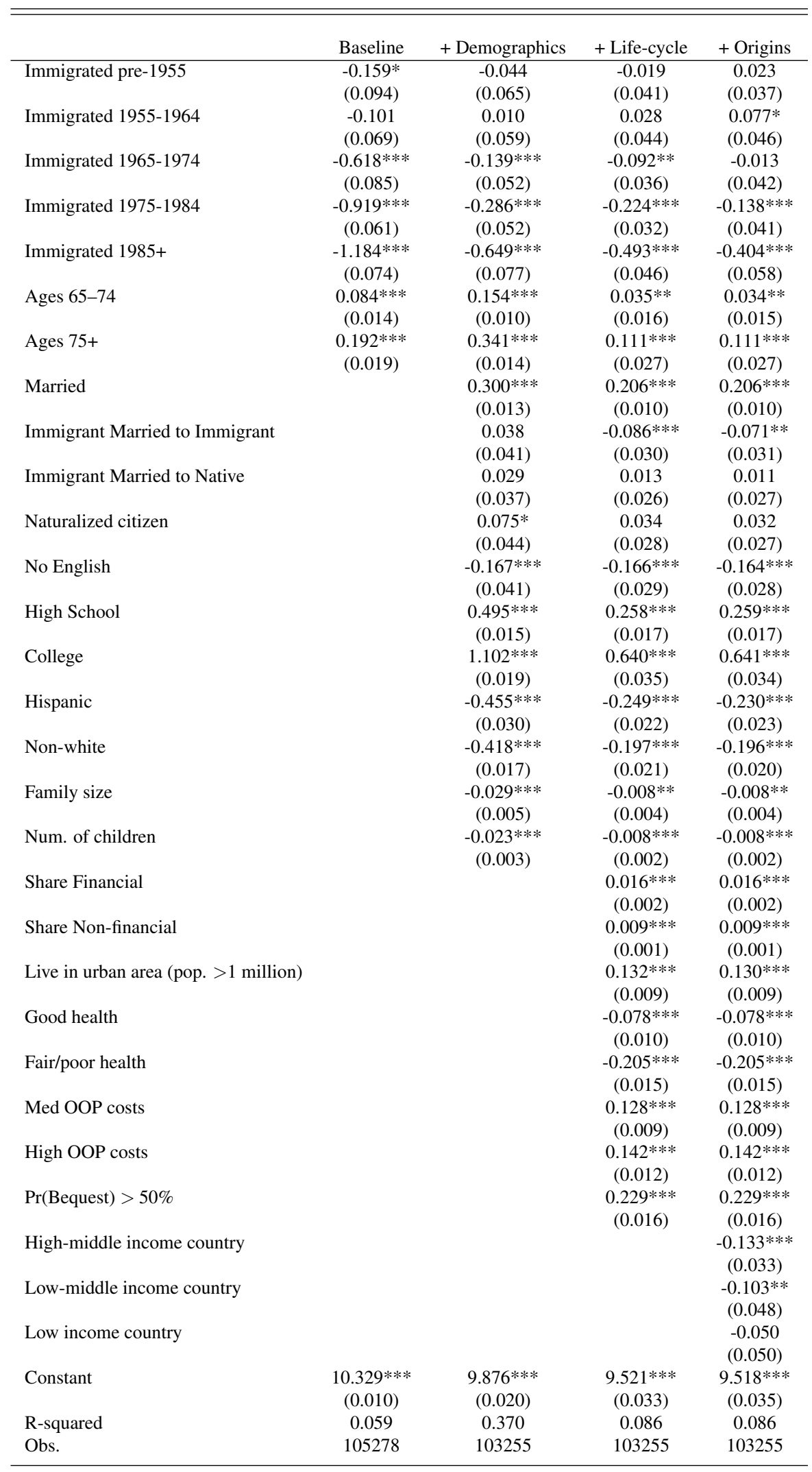

This table reports coefficient estimates and standard errors from qu3bifile regressions of the natural logarithm annualized wealth on household characteristics for households with respondents aged 51 or older in the 1998-2012 waves of the HRS. All specifications include a full set of year dummies. The HRS data were merged with restricted geocode data from the HRS. See the note under Table 4 and the main text for definitions and a discussion of the covariates. Standard errors are clustered at the household level. Asterisks denote levels of statistical significance: $* p<0.10, * * p<0.05$, *** $p<0.01$. 
Table 7

Median Regressions of Log Annualized Wealth (Immigrants), Restricted Earnings Data

\begin{tabular}{|c|c|c|c|c|}
\hline & Baseline & + Demographics & + Life-cycle & + Immigrant Race \\
\hline Immigrated 1955-1964 & $\begin{array}{c}0.203 \\
(0.125)\end{array}$ & $\begin{array}{c}0.044 \\
(0.097)\end{array}$ & $\begin{array}{c}-0.014 \\
(0.060)\end{array}$ & $\begin{array}{l}-0.016 \\
(0.053)\end{array}$ \\
\hline Immigrated 1965-1974 & $\begin{array}{c}-0.212^{* *} \\
(0.098)\end{array}$ & $\begin{array}{c}-0.225^{* * *} * \\
(0.063)\end{array}$ & $\begin{array}{l}-0.102^{*} \\
(0.054)\end{array}$ & $\begin{array}{l}-0.046 \\
(0.053)\end{array}$ \\
\hline Immigrated 1975-1984 & $\begin{array}{c}-0.533 * * * \\
(0.090)\end{array}$ & $\begin{array}{c}-0.391 * * * \\
(0.063)\end{array}$ & $\begin{array}{c}-0.200^{* * * *} \\
(0.058)\end{array}$ & $\begin{array}{c}-0.151^{*} * \\
(0.063)\end{array}$ \\
\hline Immigrated 1985+ & $\begin{array}{c}-0.786 * * * \\
(0.089)\end{array}$ & $\begin{array}{c}-0.804 * * * \\
(0.079)\end{array}$ & $\begin{array}{c}-0.248 * * * \\
(0.081)\end{array}$ & $\begin{array}{c}-0.216 * * \\
(0.085)\end{array}$ \\
\hline Ages $65-74$ & & $\begin{array}{l}0.063^{*} \\
(0.033)\end{array}$ & $\begin{array}{c}0.033 \\
(0.026)\end{array}$ & $\begin{array}{c}0.015 \\
(0.026)\end{array}$ \\
\hline Ages $75+$ & & $\begin{array}{c}0.159 * * * \\
(0.052)\end{array}$ & $\begin{array}{c}0.113 * * * \\
(0.043)\end{array}$ & $\begin{array}{c}0.076^{* * *} \\
(0.038)\end{array}$ \\
\hline Married & & $\begin{array}{c}0.285 * * * \\
(0.043)\end{array}$ & $\begin{array}{l}-0.045 \\
(0.040)\end{array}$ & $\begin{array}{l}-0.039 \\
(0.041)\end{array}$ \\
\hline High School & & $\begin{array}{c}0.576 * * * \\
(0.055)\end{array}$ & $\begin{array}{c}0.218 * * * \\
(0.039)\end{array}$ & $\begin{array}{c}0.214 * * * \\
(0.039)\end{array}$ \\
\hline College & & $\begin{array}{c}1.236 * * * \\
(0.064)\end{array}$ & $\begin{array}{c}0.556^{* * * *} \\
(0.056)\end{array}$ & $\begin{array}{c}0.502 * * * \\
(0.070)\end{array}$ \\
\hline Naturalized citizen & & $\begin{array}{l}0.078^{*} \\
(0.042)\end{array}$ & $\begin{array}{c}0.012 \\
(0.032)\end{array}$ & $\begin{array}{c}0.043 \\
(0.035)\end{array}$ \\
\hline Family size & & $\begin{array}{c}-0.030 * * * \\
(0.010)\end{array}$ & $\begin{array}{l}-0.008 \\
(0.008)\end{array}$ & $\begin{array}{c}-0.001 \\
(0.008)\end{array}$ \\
\hline Num. of children & & $\begin{array}{c}-0.029 * * * \\
(0.008)\end{array}$ & $\begin{array}{l}-0.006 \\
(0.006)\end{array}$ & $\begin{array}{l}-0.005 \\
(0.007)\end{array}$ \\
\hline Share Financial & & & $\begin{array}{c}0.022 * * * \\
(0.002)\end{array}$ & $\begin{array}{c}0.020 * * * \\
(0.003)\end{array}$ \\
\hline Share Non-financial & & & $\begin{array}{c}0.011^{* * * *} \\
(0.001)\end{array}$ & $\begin{array}{c}0.010 * * * \\
(0.001)\end{array}$ \\
\hline Log of average household earnings & & & $\begin{array}{c}0.161 * * * \\
(0.021)\end{array}$ & $\begin{array}{c}0.161 * * * \\
(0.023)\end{array}$ \\
\hline Std. of log household earnings & & & $\begin{array}{c}0.033 \\
(0.051)\end{array}$ & $\begin{array}{c}0.031 \\
(0.052)\end{array}$ \\
\hline Good health & & & $\begin{array}{c}-0.102 * * \\
(0.044)\end{array}$ & $\begin{array}{l}-0.070^{*} \\
(0.038)\end{array}$ \\
\hline Fair/poor health & & & $\begin{array}{c}-0.235^{* * *} \\
(0.049)\end{array}$ & $\begin{array}{c}-0.173 * * * \\
(0.042)\end{array}$ \\
\hline Med OOP costs & & & $\begin{array}{c}0.168 * * * \\
(0.064)\end{array}$ & $\begin{array}{c}0.169 * * * \\
(0.048)\end{array}$ \\
\hline High OOP costs & & & $\begin{array}{c}0.149 * * * \\
(0.043)\end{array}$ & $\begin{array}{c}0.105 * * \\
(0.043)\end{array}$ \\
\hline $\operatorname{Pr}($ Bequest $)>50 \%$ & & & $\begin{array}{c}0.165^{* * * *} \\
(0.028)\end{array}$ & $\begin{array}{c}0.152 * * * \\
(0.029)\end{array}$ \\
\hline Hispanic & & & & $\begin{array}{c}-0.317 * * * \\
(0.057)\end{array}$ \\
\hline Non-white & & & & $\begin{array}{c}-0.234 * * * \\
(0.065)\end{array}$ \\
\hline Constant & $\begin{array}{c}9.909 * * * \\
(0.062)\end{array}$ & $\begin{array}{c}9.569 * * * \\
(0.069)\end{array}$ & $\begin{array}{c}7.376 * * * \\
(0.305)\end{array}$ & $\begin{array}{c}7.536 * * * \\
(0.318)\end{array}$ \\
\hline R-squared & 0.100 & 0.329 & 0.425 & 0.469 \\
\hline Obs. & 9139 & 8989 & 6208 & 6200 \\
\hline
\end{tabular}

This table reports coefficient estimates and standard errors from quantile regressions of the natural logarithm annualized wealth on household characteristics for immigrant households with respondents aged 51 or older in the 1998-2012 waves of the HRS. Immigrant households consist of single immigrants or married couples in which both members are immigrants. All specifications include a full set of year dummies. The HRS data were merged with restricted earnings records from the SSA. See the note under Table 4 and the main text for definitions and a discussion of the covariates. Standard errors are clustered at the household level. Asterisks denote levels of statistical significance: $* p<0.10, * * p<0.05, * * * p<0.01$. 
Table 8

Median Regressions of Log Annualized Wealth (Immigrants), Restricted Geocode Data

\begin{tabular}{|c|c|c|c|c|c|}
\hline & Baseline & + Demographics & + Life-cycle & + Origins & + Immigrant Race \\
\hline \multirow[t]{2}{*}{ Immigrated 1955-1964 } & 0.203 & 0.044 & 0.058 & $0.085^{* *}$ & $0.079 *$ \\
\hline & $(0.125)$ & $(0.097)$ & $(0.045)$ & $(0.043)$ & $(0.041)$ \\
\hline \multirow[t]{2}{*}{ Immigrated 1965-1974 } & $-0.212 * *$ & $-0.225^{* * *} *$ & $-0.114 * * *$ & -0.048 & -0.038 \\
\hline & $(0.098)$ & $(0.063)$ & $(0.043)$ & $(0.044)$ & $(0.043)$ \\
\hline \multirow{2}{*}{ Immigrated 1975-1984 } & $-0.533 * * *$ & $-0.391 * * *$ & $-0.258 * * *$ & $-0.169 * * *$ & $-0.197 * * *$ \\
\hline & $(0.090)$ & $(0.063)$ & $(0.044)$ & $(0.046)$ & $(0.046)$ \\
\hline \multirow[t]{2}{*}{ Immigrated 1985+ } & $-0.786 * * *$ & $-0.804 * * *$ & $-0.518 * * *$ & $-0.435^{* * *}$ & $-0.463 * * *$ \\
\hline & $(0.089)$ & $(0.079)$ & $(0.062)$ & $(0.064)$ & $(0.069)$ \\
\hline \multirow[t]{2}{*}{ Ages $65-74$} & & $0.063^{*}$ & 0.025 & 0.021 & -0.001 \\
\hline & & $(0.033)$ & $(0.025)$ & $(0.023)$ & $(0.024)$ \\
\hline \multirow[t]{2}{*}{ Ages 75+ } & & $0.159 * * *$ & $0.080 * *$ & $0.075^{* *}$ & 0.040 \\
\hline & & $(0.052)$ & $(0.035)$ & $(0.032)$ & $(0.034)$ \\
\hline \multirow[t]{2}{*}{ Married } & & $0.285 * * *$ & $0.088 * * *$ & $0.085^{* * *}$ & $0.103 * * *$ \\
\hline & & $(0.043)$ & $(0.030)$ & $(0.030)$ & $(0.031)$ \\
\hline \multirow[t]{2}{*}{ High School } & & $0.576 * * *$ & $0.275 * * *$ & $0.264 * * *$ & $0.233 * * *$ \\
\hline & & $(0.055)$ & $(0.033)$ & $(0.034)$ & $(0.034)$ \\
\hline \multirow[t]{2}{*}{ College } & & $1.236 * * *$ & $0.654 * * *$ & $0.633 * * *$ & $0.578 * * *$ \\
\hline & & $(0.064)$ & $(0.047)$ & $(0.048)$ & $(0.051)$ \\
\hline \multirow[t]{2}{*}{ Naturalized citizen } & & $0.078^{*}$ & 0.026 & $0.049^{*}$ & 0.044 \\
\hline & & $(0.042)$ & $(0.029)$ & $(0.028)$ & $(0.029)$ \\
\hline \multirow[t]{2}{*}{ Family size } & & $-0.030 * * *$ & $-0.021 * * *$ & $-0.014 *$ & -0.011 \\
\hline & & $(0.010)$ & $(0.008)$ & $(0.007)$ & $(0.007)$ \\
\hline \multirow[t]{2}{*}{ Num. of children } & & $-0.029 * * *$ & -0.001 & -0.002 & -0.001 \\
\hline & & $(0.008)$ & $(0.005)$ & $(0.006)$ & $(0.005)$ \\
\hline \multirow[t]{2}{*}{ Share Financial } & & & $0.023 * * *$ & $0.022 * * *$ & $0.021 * * *$ \\
\hline & & & $(0.001)$ & $(0.001)$ & $(0.001)$ \\
\hline \multirow[t]{2}{*}{ Share Non-financial } & & & $0.011 * * *$ & $0.011^{* * *}$ & $0.010 * * *$ \\
\hline & & & $(0.001)$ & $(0.001)$ & $(0.001)$ \\
\hline \multirow[t]{2}{*}{ Live in urban area (pop. $>1$ million) } & & & $0.191 * * *$ & $0.155^{* * *}$ & $0.164 * * *$ \\
\hline & & & $(0.031)$ & $(0.030)$ & $(0.032)$ \\
\hline \multirow[t]{2}{*}{ Good health } & & & $-0.125^{* * *}$ & $-0.112 * * *$ & $-0.100 * * *$ \\
\hline & & & $(0.033)$ & $(0.030)$ & $(0.033)$ \\
\hline \multirow[t]{2}{*}{ Fair/poor health } & & & $-0.281 * * *$ & $-0.259 * * *$ & $-0.240 * * *$ \\
\hline & & & $(0.036)$ & $(0.033)$ & $(0.035)$ \\
\hline \multirow{2}{*}{ Med OOP costs } & & & $0.168 * * *$ & $0.179 * * *$ & $0.167 * * *$ \\
\hline & & & $(0.024)$ & $(0.023)$ & $(0.022)$ \\
\hline \multirow[t]{2}{*}{ High OOP costs } & & & $0.168 * * *$ & $0.157 * * *$ & $0.127 * * *$ \\
\hline & & & $(0.025)$ & $(0.026)$ & $(0.026)$ \\
\hline $\operatorname{Pr}($ Bequest $)>50 \%$ & & & $0.220 * * *$ & $0.215^{* * *}$ & $0.218 * * *$ \\
\hline & & & $(0.025)$ & $(0.025)$ & $(0.026)$ \\
\hline High-middle income country & & & & $-0.168 * * *$ & -0.057 \\
\hline & & & & $(0.034)$ & $(0.037)$ \\
\hline Low-middle income country & & & & $-0.197 * * *$ & $-0.126^{* *}$ \\
\hline & & & & $(0.046)$ & $(0.056)$ \\
\hline Low income country & & & & $-0.105^{* *}$ & -0.044 \\
\hline & & & & $(0.051)$ & $(0.058)$ \\
\hline Hispanic & & & & & $-0.276^{* * *}$ \\
\hline & & & & & $(0.046)$ \\
\hline Non-white & & & & & $-0.121 *$ \\
\hline & & & & & $(0.065)$ \\
\hline Constant & $9.909 * * *$ & $9.569 * * *$ & $9.265 * * *$ & $9.328 * * *$ & $9.469 * * *$ \\
\hline & $(0.062)$ & $(0.069)$ & $(0.056)$ & $(0.058)$ & $(0.067)$ \\
\hline R-squared & 0.100 & 0.329 & 0.379 & 0.389 & 0.409 \\
\hline Obs. & 9139 & 8989 & 8989 & 8989 & 8976 \\
\hline
\end{tabular}

This table reports coefficient estimates and standard errors from quantile regressions of the natural logarithm annualized wealth on household characteristics for immigrant households with respondents aged 51 or older in the 1998-2012 waves of the HRS. Immigrant households consist of single immigrants or married couples in which both members are immigrants. All specifications include a full set of year dummies. The HRS data were merged with restricted geocode data from the HRS. See the note under Table 4 and the main text for definitions and a discussion of the covariates. Standard errors are clustered at the household level. Asterisks denote levels of statistical significance: * $p<0.10$, ** $p<0.05$, *** $p<0.01$. 


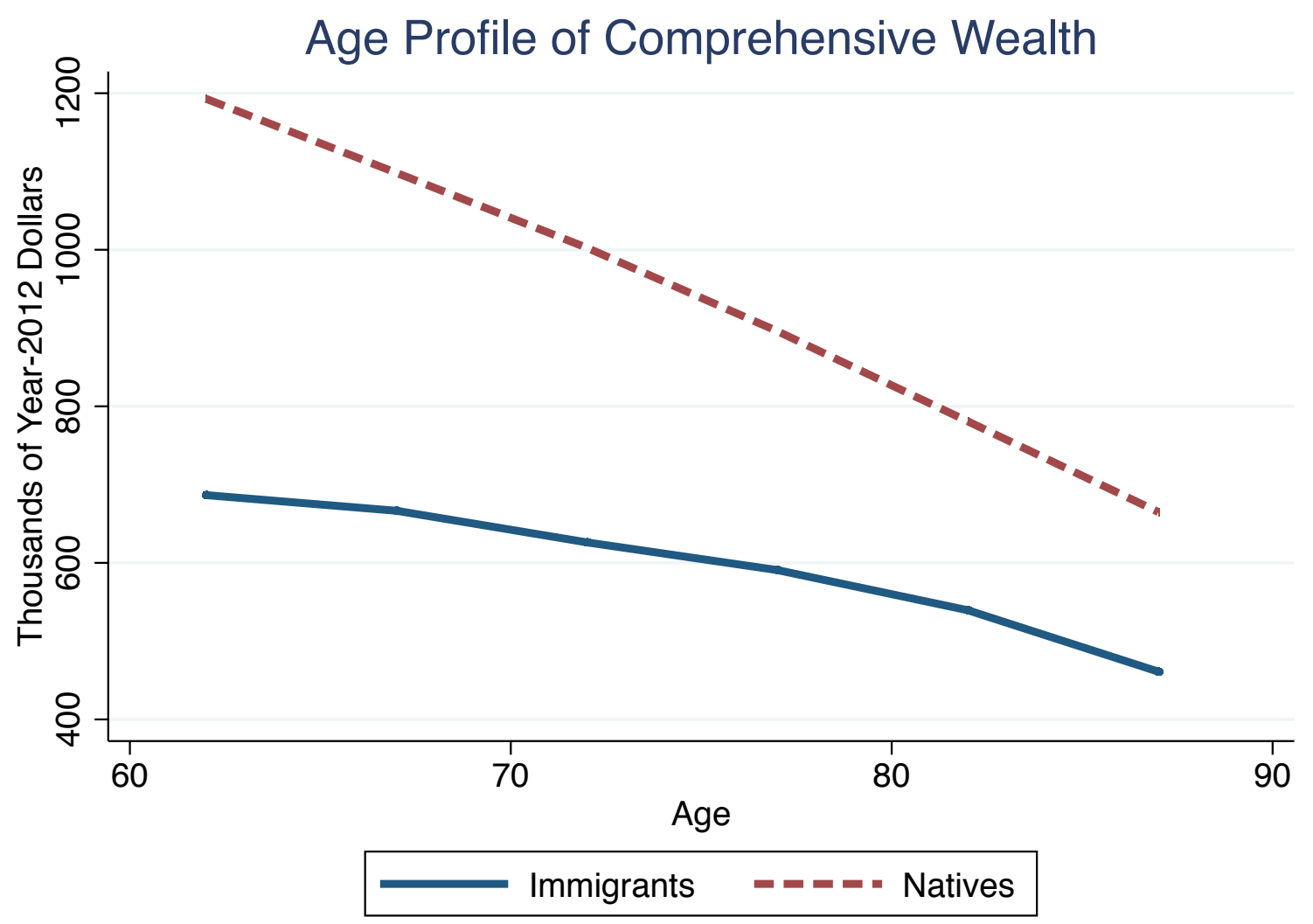

Figure 1

Comprehensive Wealth Profiles: This figure displays comprehensive wealth profiles for married households aged 65 and older in the 1998-2012 waves of the HRS. Households are treated as married if they are married in the first wave they are observed. The profiles are constructed using the coefficient estimates on a set of two-year age dummies from a median regression of the growth of annualized wealth that includes a full set of year dummies. See text for details. 


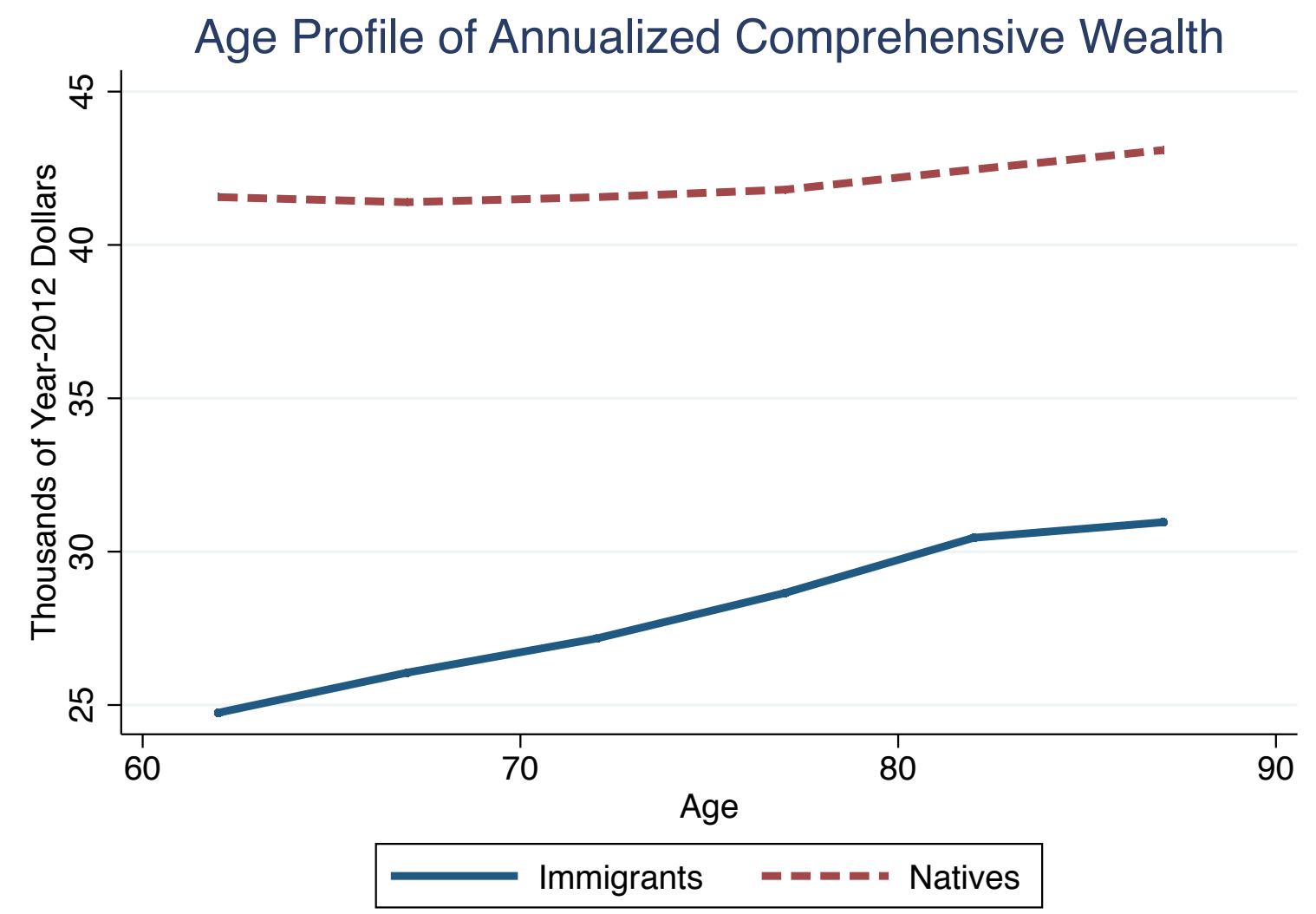

Figure 2

Annualized Comprehensive Wealth Profiles for Married Households: This figure displays annualized comprehensive wealth profiles for married households aged 65 and older in the 1998-2012 waves of the HRS. Households are treated as married if they are married in the first wave they are observed. The profiles are constructed using the coefficient estimates on a set of two-year age dummies from a median regression of the growth of annualized wealth that includes a full set of year dummies. See text for details. 


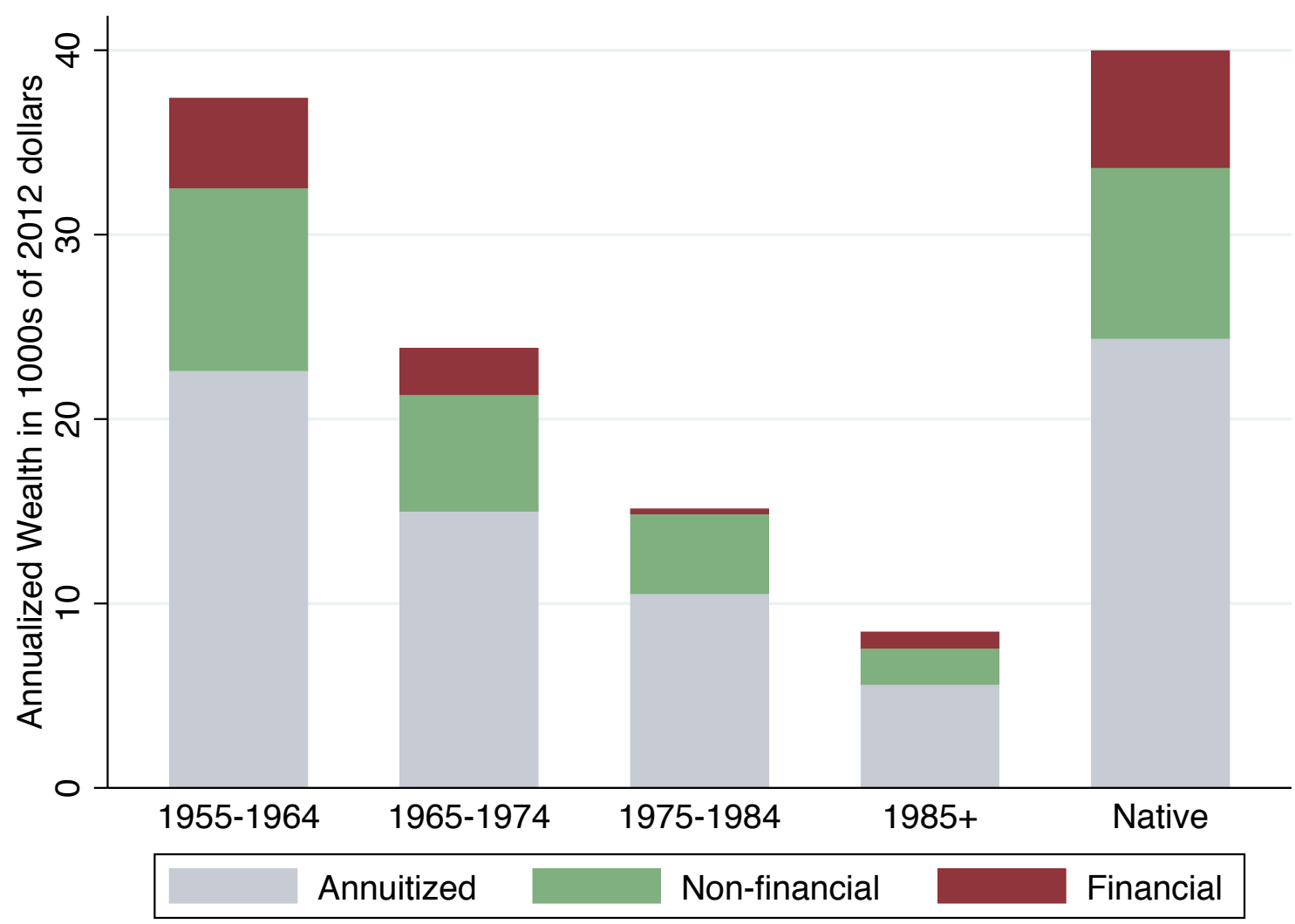

Figure 3

Annualized Wealth by Immigration Cohort: This chart displays the median value of annualized wealth broken down into annuitized, financial, and nonfinancial components for married households aged 65-74 in the 1998-2012 waves of the HRS. Households are treated as married if they are married in the first wave they are observed. See text for details. 

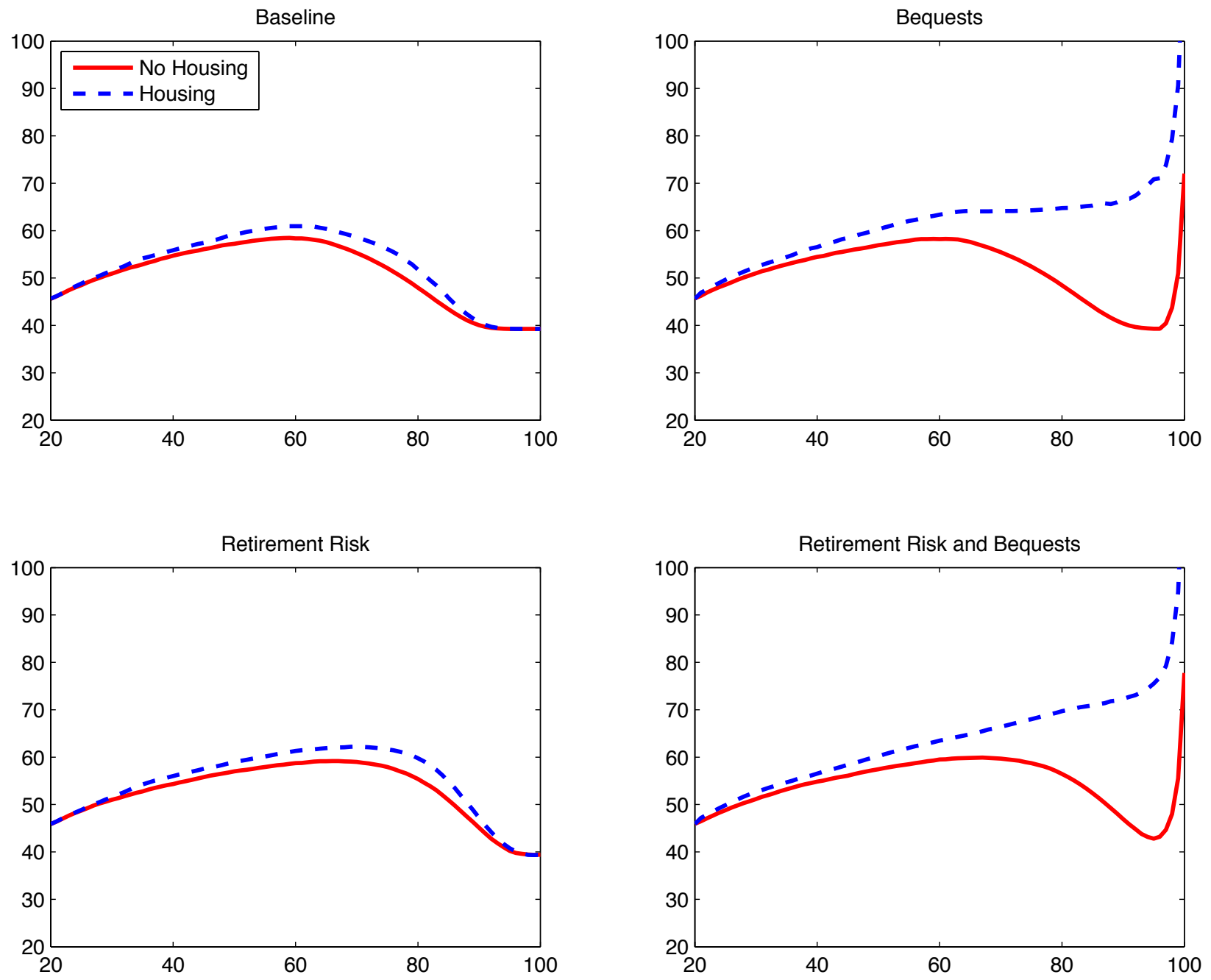

Figure 4

Simulated Annualized Wealth Profiles for High School Graduates: This figure shows simulated mean annualized wealth by age ( $x$-axis) for different specifications of the model: baseline with no retirement risk or bequest motive (top left), risk and no bequest motive (bottom left), bequest motive and no risk (top right), and bequest motive and retirement risk (bottom right). Annualized wealth is in 1000 s of year-2010 dollars. 